\title{
Observation of aerosol size distribution and new particle formation at a mountain site in subtropical Hong Kong
}

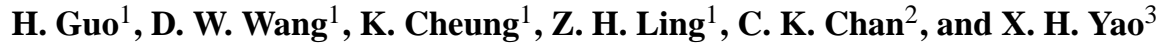 \\ ${ }^{1}$ Air Quality Studies, Department of Civil and Environmental Engineering, The Hong Kong Polytechnic University, \\ Hong Kong, China \\ ${ }^{2}$ Division of Environment and Department of Chemical and Biomolecular Engineering, The Hong Kong University of \\ Science and Technology, Hong Kong, China \\ ${ }^{3}$ Key Lab of Marine Environmental Science and Ecology, Ministry of Education, Ocean University of China, Qingdao, China
}

Correspondence to: H. Guo (ceguohai@ polyu.edu.hk)

Received: 28 March 2012 - Published in Atmos. Chem. Phys. Discuss.: 10 May 2012

Revised: 10 October 2012 - Accepted: 10 October 2012 - Published: 30 October 2012

\begin{abstract}
In order to investigate the formation and growth processes of nucleation mode particles, and to quantify the particle number (PN) concentration and size distributions in Hong Kong, an intensive field measurement was conducted from 25 October to 29 November in 2010 near the mountain summit of Tai Mo Shan, a suburban site approximately the geographical centre of the New Territories in Hong Kong. Based on observations of the particle size distribution, new particle formation (NPF) events were found on 12 out of 35 days with the estimated formation rate $J_{5.5}$ from 0.97 to $10.2 \mathrm{~cm}^{-3} \mathrm{~s}^{-1}$, and the average growth rates from 1.5 to $8.4 \mathrm{~nm} \mathrm{~h}^{-1}$. The events usually began at 10:0011:00 LT characterized by the occurrence of a nucleation mode with a peak diameter of 6-10 $\mathrm{nm}$. Solar radiation, wind speed, sulfur dioxide $\left(\mathrm{SO}_{2}\right)$ and ozone $\left(\mathrm{O}_{3}\right)$ concentrations were on average higher, whereas temperature, relative humidity and daytime nitrogen dioxide $\left(\mathrm{NO}_{2}\right)$ concentration were lower on NPF days than on non-NPF days. Back trajectory analysis suggested that in majority of the NPF event days, the air masses originated from the northwest to northeast directions. The concentrations of gaseous sulfuric acid (SA) showed good power-law relationship with formation rates, with exponents ranging from 1 to 2 . The result suggests that the cluster activation theory and kinetic nucleation could potentially explain the observed NPF events in this mountainous atmosphere of Hong Kong. Meanwhile, in these NPF events, the contribution of sulfuric acid vapor to particle growth rate $\left(\mathrm{GR}_{5.5-25}\right)$ ranged from 9.2 to $52.5 \%$ with an average of $26 \%$. Measurement-based cal-
\end{abstract}

culated oxidation rates of monoterpenes (i.e. $\alpha$-pinene, $\beta$ pinene, myrcene and limonene) by $\mathrm{O}_{3}$ positively correlated with the $\mathrm{GR}_{5.5-25}(R=0.80, p<0.05)$. The observed associations of the estimated formation rate $J_{5.5}$ and the growth rate $\mathrm{GR}_{5.5-25}$ with gaseous sulfuric acid and volatile organic compounds (VOCs) suggested the critical roles of sulfuric acid and biogenic VOCs (e.g. $\alpha$-pinene and $\beta$-pinene) in these NPF events.

\section{Introduction}

The formation and growth of atmospheric aerosols has recently received increasing attention as a potentially important source of aerosol particles affecting climate and human health (e.g. Penner et al., 2004; Kovats and Haines, 2005; Davidson et al., 2005). The freshly formed aerosols become climatically important when they are able to grow to sizes of $50 \mathrm{~nm}$ and larger. Particles in this size range can act as cloud condensation nuclei (CCN), significantly increasing the indirect radiative effect of clouds (e.g. McMurry et al., 2011). Moreover, due to their nanometer-scale size, the newly formed particles can penetrate into the ciliated and alveolar sections of the lung and even bloodstream (Oberdörster et al., 2005), contributing to negative health effects. Consequently, advancing our understanding on the formation and growth processes of these new particles in the atmosphere has become critically important. 
To date, numerous measurements have been conducted in different locations to study the size distribution of submicrometer particles and new particle formation (NPF) processes, including clean areas, i.e. free troposphere (e.g. Weber et al., 2001), boreal forests (e.g. Vehkamäki et al., 2004; Dal Maso et al., 2007; Asmi et al., 2011), coastal rural areas (e.g. Lee et al., 2008), high mountain-top (e.g. Gannet et al., 2011), Antarctic/Arctic areas (e.g. Park et al., 2004); and polluted urban areas, i.e. Atlanta (Woo et al., 2001), Pittsburgh (Stanier et al., 2004a, b), Birmingham, UK (Alam et al., 2003), Mexico City (Dunn et al., 2004), East St. Louis (Qian et al., 2007), and Brisbane (Guo et al., 2008; Cheung et al., 2011). Generally, NPF events are much more frequently observed in rural/remote areas than in urban locations. In China, the field measurements for particle size distribution were carried out in several cities and regions in recent years. Short-term intensive studies on NPF were performed in Beijing (Yue et al., 2009), Pearl River Delta (PRD) (Liu et al., 2008), Yangtze River Delta (YRD) (Gao et al., 2009) and Hong Kong (Yao et al., 2010). Moreover, a couple of longterm continuous measurements were conducted in Beijing (e.g. Wu et al., 2008; Shen et al., 2011) and a remote mountain site, Mt. Waliguan (Kivekäs et al., 2009).

A variety of formation mechanisms have been suggested for atmospheric aerosols (Kulmala et al., 2000). Generally, the formation of nucleation mode particle requires two processes: the nucleation of stable atmospheric clusters (1$3 \mathrm{~nm})$ and the growth of these clusters into observable sizes $(>3 \mathrm{~nm})$. Altogether, the driving force for nucleation and the growth of freshly formed particles is the sufficiently high concentration of condensational vapors, such as sulfuric acid and possibly other organic compounds with a low saturation vapor pressure formed by photochemical oxidation reaction. Sulfuric acid has been found to be a key compound in atmospheric nucleation in many studies (Kulmala et al., 2006; Riipinen et al., 2007; Sipilä et al., 2010). Also recent study (e.g. Kerminen et al., 2010) found that some organic acids produced from monoterpene oxidation can nucleate with sulfuric acid to form very stable clusters. However, for particle growth, observations suggest that the contribution of sulfuric acid to particle growth is typically from a few percents to some tens of percents of the observed particle growth rate (Boy et al., 2005; Nieminen et al., 2010; Riipinen et al., 2011), while organics with a very low saturation vapor pressure (Tunved et al., 2006; Jimenez et al., 2009) can be considered as the most probable candidates of the vapors responsible for the fraction of nucleation mode growth that is not explained by sulfuric acid. For example, boreal forest observations in Finland indicated a connection between nucleation mode growth and ambient concentrations of monoterpenes (Laaksonen et al., 2008). In Hong Kong, no study has been undertaken to study the characteristics of NPF events. The potential mechanisms and compounds participating in atmospheric NPF and growth in this region have remained unclear. Therefore, it is important to enrich the database of particle number size distribution, and to investigate the NPF and growth processes in this urban area.

In this study, an intensive field measurement was conducted from 25 October to 29 November in 2010 near the summit of Mt. Tai Mo Shan (TMS; 640 m a.s.1). The PN size distributions were characterized and the NPF events were classified based on their strength and growth of geometric mean diameter (GMD). Moreover, the favorable meteorological conditions and possible mechanisms for the nucleation and growth of new particles were discussed by analyzing concurrently-observed meteorological parameters, gaseous pollutants, major hydrocarbons (e.g. isoprene, $\alpha-/ \beta$-pinenes, myrcene, limonene and aromatics), and carbonyl compounds i.e. formaldehyde, acetaldehyde and acetone.

\section{Methodology}

\subsection{The topography and climate of Hong Kong}

Hong Kong $\left(22^{\circ} 15^{\prime} \mathrm{N}, 114^{\circ} 10^{\prime} \mathrm{E}\right)$ is a coastal city located in the PRD region with a total land area of $1104 \mathrm{~km}^{2}$ and a population of 7 million, surrounded by the South China Sea on the east, south, and west, and borders the Guangdong city of Shenzhen to the north over the Shenzhen River. The highest elevation in the territory is at TMS (957 m a.s.l.). Due to Hong Kong's special geographical location and complex atmospheric conditions, Hong Kong climate can be affected by some severe weather phenomena, i.e. tropical cyclones and strong winter monsoon. Generally the dry monsoon season covers September, October and November when the north and northeast synoptic winds from inland PRD and eastern China coast dominate.

\subsection{The sampling site}

Mt. TMS is claimed to be Hong Kong's most misty area due to the high daily cloud coverage. The highest point on Mt. TMS is occupied by a Hong Kong Observatory weather radar station. Our monitoring site was located at the waist of Mt. TMS near the mountain summit $\left(22.405^{\circ} \mathrm{N}, 114.118^{\circ} \mathrm{E}\right.$, about 640 m a.s.l.) (see Fig. 1).

Surrounding the foot of the mountain are urban centers with a population of 2.23 million. The straight distances between the mountain summit and the urban centers at the foot are about $5-10 \mathrm{~km}$. Farther to the south are the urban centers of the partial New Territory, Kowloon peninsula and Hong Kong Island. To the southwest is the newly-developed residential area of Tung Chung, the international airport and the South China Sea. To the west are the Tuen Mun residential areas and to the south is the South China Sea. To the north and northeast are the city clusters of the inland PRD region. The prevailing north/northeast synoptic winds in OctoberNovember bring polluted air on some days and clean air on some other days from inland PRD and eastern China coast to the sampling site, depending on the weather conditions at 


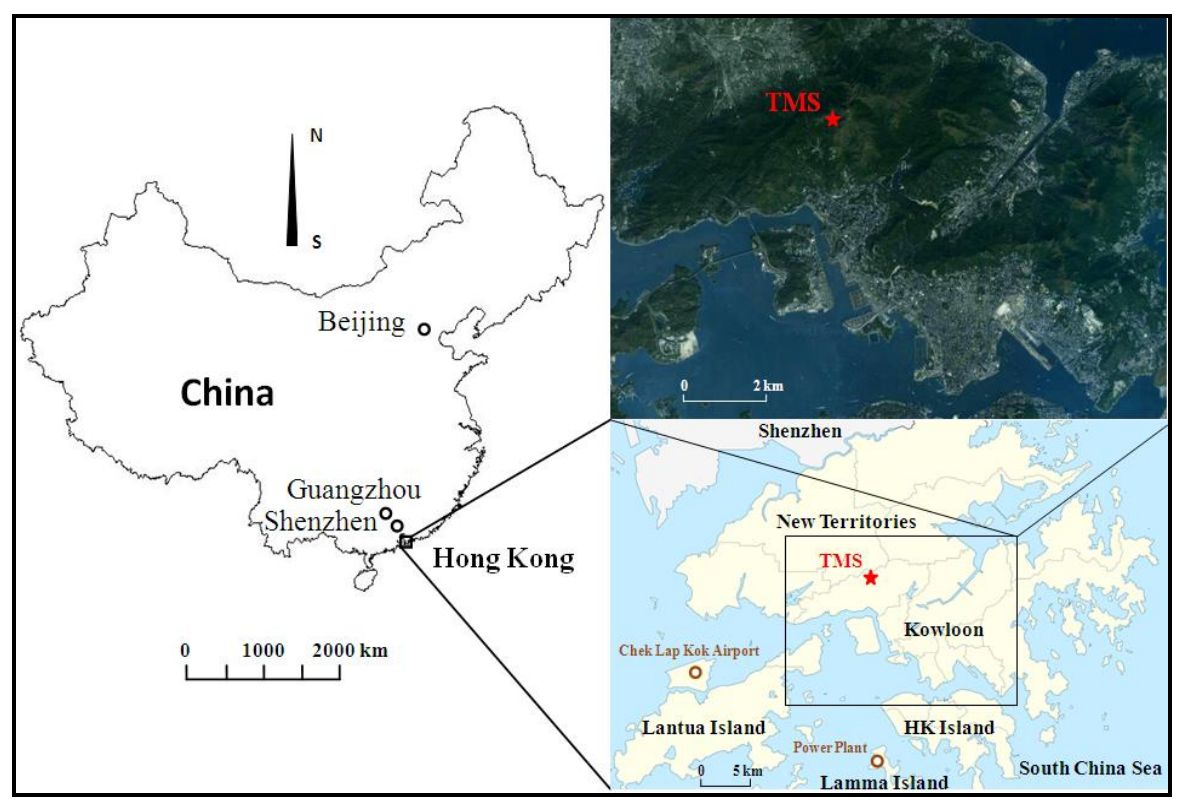

Fig. 1. Locations of Hong Kong and the TMS sampling site.

upwind locations. In addition, because of its unique topography, mountain-valley breezes and sea-land breezes are frequently observed at TMS. These mesoscale circulations enhance the interaction of polluted urban air and the mountain air.

\subsection{Measurement techniques}

Particle size distributions in the range of 5.5 to $350 \mathrm{~nm}$ were continuously measured by a Scanning Mobility Particle Sizer (SMPS, model 5.400, GRIMM, Germany) and a Condensation Particle Counter (CPC, model 5.400, GRIMM, Germany) system with 44 size bins at 4 -min scan intervals. The SMPS was equipped with a nano-differential mobility analyzer (DMA), which separated poly-disperse particles into selected mono-disperse particles according to the electrical mobility of the particles, a function of their size. Then the CPC counted the number concentration of mono-disperse particles by laser light scattering. A sample air flow rate of $0.31 \mathrm{~min}^{-1}$ was fixed for the set of SMPS + CPC with a sheath air flow rate of $3.01 \mathrm{~min}^{-1}$. In order to control the relative humidity $(\mathrm{RH})$ during sampling campaign, the aerosol samples taken from ambient air have been dried with a $0.6 \mathrm{~m}$ long diffusion silica gel drier (GRIMM) before entering the sampling system. Meanwhile, the sheath air in DMA was dried with a sheath-air dryer (GRIMM). To minimize the particle loss, ambient aerosols were drawn into the SMPS + CPC system through a $1 \mathrm{~m}$ long flexible and conductive tube with an inner diameter of $0.8 \mathrm{~cm}$. Due to significant diffusion loss of particles with size below $10 \mathrm{~nm}$ and diffusion broadening effect in the transfer function, it is important to understand the efficiency (or penetration rate) of the DMA for the accu- rate measurement of airborne particles. An experimental system determining the aerosol losses in the DMA and the calibration of the SMPS was established and discussed in Wang et al. (2012). In addition, since the Grimm CPC is not widely used, the discrepancy between Grimm CPC and TSI CPC reported by Schlatter (2006) was used to compare our results with other studies. The CPC counting efficiency and particle diffusion losses in the tubing were taken into account in the data analysis.

To understand the relationships among newly formed particles and trace gases, ambient ozone $\left(\mathrm{O}_{3}\right)$, carbon monoxide $(\mathrm{CO})$, sulfur dioxide $\left(\mathrm{SO}_{2}\right)$ and nitric oxide $(\mathrm{NO})$ concentrations were monitored. $\mathrm{O}_{3}$ was measured using a commercial UV photometric instrument (Advanced Pollution Instrumentation (API), Model 400E) with a detection limit of $0.6 \mathrm{ppbv}$. Sulfur dioxide $\left(\mathrm{SO}_{2}\right)$ was measured by pulsed UV fluorescence (API, model 100E) that has a detection limit of $0.4 \mathrm{ppbv}$. Trace level $\mathrm{CO}$ analyzer was measured with a gas filter correlation, non-dispersive infrared analyzer (API, Model 300EU). Oxides of nitrogen $\left(\mathrm{NO}-\mathrm{NO}_{2}-\mathrm{NO}_{\mathrm{x}}\right.$ ) were detected with an API-Teledyne Model 200E analyzer utilizing chemiluminesence with a detection limit of $0.4 \mathrm{ppbv}$. A data logger (Environmental Systems Corporation, Model 8832) was used to control the zero/span calibration and to collect 1-s data, which were averaged to 1-min values. Detailed description was given in Guo et al. (2012). To investigate the potential associations of individual VOCs and carbonyl compounds with NPF and particle growth, non-methane hydrocarbons (NMHCs) and carbonyl samples were collected on $\mathrm{O}_{3}$ episode days $\left(\mathrm{O}_{3} \geq 90 \mathrm{ppbv}\right)$, based on the prediction of meteorological conditions and the review of the PN concentrations on previous days, which were usually related to 
strong solar radiation, cool and dry air, and low number concentrations of pre-existing large size particles.

Ambient VOC samples were collected using cleaned and evacuated 2-1 electro-polished stainless steel canisters. A flow-controlling device was used to collect 1-h integrated samples. Hourly samples were consecutively collected from 09:00 to 16:00 with additional samples collected at 00:00, 03:00, 07:00, 18:00 and 21:00 per day. Finally, 91 VOC samples were collected at TMS on the eight days. The detailed analytical systems and the quality control and assurance for VOC analyses are described in Guo et al. (2009).

Carbonyl samples were collected on the same sampling days using the silica cartridges impregnated with acidified 2,4-dinitrophenylhydrazine (DNPH). Air samples were drawn through the cartridge at a flow rate of $0.8-0.91 \mathrm{~min}^{-1}$ for $120 \mathrm{~min}(2 \mathrm{~h})$; the flow rate through the cartridges was monitored with a rotameter which was calibrated before and after each sampling. An $\mathrm{O}_{3}$ scrubber was connected to the inlet of the DNPH-silica cartridge to prevent interference from $\mathrm{O}_{3}$. During these sampling days, carbonyls samples were consecutively collected from 07:00 to 21:00 every two hours with additional samples collected at 00:00 and 03:00. Finally, 70 carbonyl samples were collected during this sampling period. All cartridges were stored in a refrigerator at $4{ }^{\circ} \mathrm{C}$ after sampling. The sampled carbonyl cartridges were eluted slowly with $2 \mathrm{ml}$ of acetonitrile into a 2-ml volumetric flask. A 20- $\mu$ l aliquot was injected into the high performance liquid chromatography (HPLC) system through an auto-sampler. The operating conditions of the HPLC and the quality control and detection limit for carbonyl compounds are also provided in Guo et al. (2009).

The meteorological conditions were continuously monitored using a mini-weather station (Vantage Pro TM \& Vantage Pro 2 - TM Weather Stations, Davis Instruments), which consists of two components: a sleekly designed integrated sensor suite (ISS) to measure outdoor weather conditions, and a data-receiving console to receive the weather data wirelessly. The weather station was placed on the rooftop of a building at the TMS site. Temperature, relative humidity, solar radiation, UV light, wind speed and direction were recorded during the sampling period.

\subsection{Data processing and analysis}

Typically, the sizes of submicrometer particles are categorized into three modes: a nucleation mode, representing quite newly formed particles; Aitken and accumulation modes, representing aged particles. In this study, we divided the size distribution into 5.5-10 (nucleation mode, $N_{\text {nuc }}$ ), 10-100 (Aitken mode, $N_{\text {Ait }}$ ), and 100-350 nm (accumulation mode, $N_{\text {acc }}$ ). The PN concentrations in nucleation mode, Aitken mode, and accumulation mode were calculated with a $95 \%$ confidence level $(p<0.05)$. The correlation coefficients and p-values between the different tested parameters were calculated.

\subsubsection{Definition of particle formation event}

In this study, NPF events were classified into three groups (Classes Ia, Ib and II) according to the classification scheme developed by Dal Maso et al. (2005), following the criteria that the particle mode must start in the distinct nucleation mode size and the particle mode must show signs of growth with a time span of hours. Class I presents the days when the formation and growth rate are determined with a good confidence level. Class I is divided into Class Ia and Ib. The Class Ia event has clear and strong particle formation with little or no pre-existing particles, while a Class Ib event is any other Class I event where the particle formation and growth rate still can be determined. A Class II event represents the event where the accuracy of formation rate calculation is questionable due to data fluctuation even though the banana shapes are still observable. Days with no particle formation observed are classified as non-NPF event days, due to the absence of particles in nucleation mode size range.

\subsubsection{Calculation of formation rate $\left(J_{5.5}\right)$, growth rate (GR 5.5-25) and condensational sink (CS)}

In this study, $5.5 \mathrm{~nm}$ particle formation rate (FR, $J_{5.5}$ ) was represented and quantified by the following equation (Sihto et al., 2006), taking into account the coagulation losses and growth losses:

$$
\begin{aligned}
J_{5.5} & =\frac{\mathrm{d} N_{5.5-10}}{\mathrm{~d} t}+\operatorname{Coag} S_{d_{\mathrm{p}=7 \mathrm{~nm}}} \cdot N_{5.5-10} \\
& +\frac{1}{4.5 \mathrm{~nm}} \mathrm{GR}_{5.5-10} \cdot N_{5.5-10}
\end{aligned}
$$

where, $J_{5.5}$ is the formation rate of new particles into the measurable range of above $5.5 \mathrm{~nm}$. The coagulation loss for the interval $5.5-10 \mathrm{~nm}$ was approximated by a term representing loss of $7 \mathrm{~nm}$ sized particles $(7 \mathrm{~nm}$ is approximately the geometric mean of 5.5 and $10 \mathrm{~nm}$ ) with the concentration of $N_{5.5-10}$. The third term represents the loss due to condensation out of the 5.5-10 nm size range. Here the observed growth rate (GR) in the size range of $5.5-10 \mathrm{~nm}$ was quantified using the "mode fitting" method (Dal Maso et al., 2005). As only one line fitting is done for each particle formation event, this method assumes the growth rate to be constant throughout the event.

The evolution of modal geometric mean diameters (GMD) (Dal Maso et al., 2005) in a size range of 5.5-25 nm for each size distribution with a 4-min resolution was used to examine particle growth processes:

$\mathrm{GR}_{5.5-25}=\frac{\Delta \mathrm{GMD}}{\Delta t}$

The condensation sink (CS) of newly formed particles, presented as the loss rate of molecules onto existing particles, was estimated by integrating over the aerosol size 
distribution as follows (Kulmala et al., 2005):

$$
\begin{aligned}
\mathrm{CS} & =2 \pi D \int D_{\mathrm{p}} \beta_{M}\left(D_{\mathrm{p}}\right) n\left(D_{\mathrm{p}}\right) \mathrm{d} D_{\mathrm{p}} \\
& =2 \pi D \sum_{i} \beta_{M i} D_{\mathrm{p} i} N_{i}
\end{aligned}
$$

where $D$ is the diffusion coefficient of the condensing vapour, $\beta_{M}$ is the transitional regime correction factor, $D_{\mathrm{p} i}$ is the particle diameter in size class $i$, and $N_{i}$ is the PN concentration in the respective size class. For the particle diameter $D_{\mathrm{p} i}$ used in the Eq. (3), the measured dry size spectra were converted to wet size spectra by particle growth factor (GF) according to ambient relative humidity (Laakso et al, 2004).

\subsubsection{Contribution of sulfuric acid (SA)}

To investigate the contribution of sulfuric acid (SA) vapor on the particle formation and growth, a predictive proxy based on global solar radiation, $\mathrm{SO}_{2}$ concentration, condensation sink and relative humidity was used to estimate sulfuric acid concentrations (Mikkonen et al., 2011):

$$
\begin{aligned}
Q_{\mathrm{SA}} & =8.21 \times 10^{-3} \cdot k \cdot \text { Radiation } \cdot\left[\mathrm{SO}_{2}\right]^{0.62} \\
& \cdot(\mathrm{CS} \cdot \mathrm{RH})^{-0.13}
\end{aligned}
$$

where, $Q_{\mathrm{SA}}\left(\mathrm{cm}^{-3} \mathrm{~s}^{-1}\right)$ is the source rate of $\mathrm{SA}$, and $k$ is a constant value 1.035 .

\subsubsection{Contribution of Biogenic VOCs}

Recent studies found that the growth rates of newly formed particles had positive correlations with monoterpene concentrations and their oxidation rates by $\mathrm{O}_{3}$ not by $\mathrm{OH}$ radical (Yli-Juuti et al., 2011; Hao et al., 2011). The production rates of oxidation products of monoterpenes by $\mathrm{O}_{3}$ in these NPF events were calculated from measured monoterpene (i.e. $\alpha$ $/ \beta$-pinenes, myrcene, and limonene) and $\mathrm{O}_{3}$ concentrations (Yli-Juuti et al., 2011):

$$
[\mathrm{OR}]_{\mathrm{O}_{3}}=k_{\mathrm{O}_{3}} \cdot\left[\mathrm{O}_{3}\right] \cdot[\text { Monoterpene }]
$$

where the rate constant $k_{\mathrm{O}_{3}}=1.4 \times 10^{-17} \mathrm{~cm}^{3}$ molecules ${ }^{-1} \mathrm{~s}^{-1}$.

\section{Results and discussion}

\subsection{Classification of the new particle formation events and ozone pollution events}

Supplement Fig. S1a shows the temporal variations of PN size distribution $(5.5-350 \mathrm{~nm})$, trace gases $\left(\mathrm{SO}_{2}, \mathrm{NO}, \mathrm{CO}\right.$ and $\mathrm{O}_{3}$ ) and meteorological conditions (solar radiation, $T$, $\mathrm{RH}$ and wind) during these NPF events in October and November 2010. According to the classification scheme developed by Dal Maso et al. (2005), the typical Class Ia events occurred on 27, 28, 29 October and 1 November 2010 at
TMS. The examples of Class Ib included 30 October, 2, 8 and 9 November 2010. On 31 October, 11, 12 and 26 November, Class II events were observed. Figure S1b shows the average diurnal variations of particle number size distribution in NPF events and non-NPF events.

Previous studies indicated that air pollution caused by ultrafine particulate matter and $\mathrm{O}_{3}$ in the atmosphere of Hong Kong is severe (e.g. Wang et al., 2005; Guo et al., 2009). It is well-known that both biogenic and anthropogenic VOCs together with nitrogen oxides $\left(\mathrm{NO}_{\mathrm{x}}\right)$ are important precursors of surface-level $\mathrm{O}_{3}$, and the oxidation products of photochemical reaction may play a key role in determining the spatial and temporal features of the nucleation events. Hence, NPF events likely occur along with photochemical $\mathrm{O}_{3}$ production. In this study, all the NPF events indeed occurred on the $\mathrm{O}_{3}$ episode days, while a few non-NPF events were also observed on $\mathrm{O}_{3}$ episode days. Based on the levels of particle number and/or $\mathrm{O}_{3}$ collected from 25 October to 29 November, four different types of events were classified from the NPF and non-NPF events throughout the 35 sampling days. Table 1 summarizes the four different types of events including (i) (12 days): all NPF events (class Ia, Ib and II events) on $\mathrm{O}_{3}$ episode days (maximum hourly $\mathrm{O}_{3}$ mixing ratio $\geq 90 \mathrm{ppbv}$ ); (ii) (4 days): non-NPF events on $\mathrm{O}_{3}$ episode days; (iii) (3 days): non-NPF events on non- $\mathrm{O}_{3}$ episode days with high particle number concentrations (PN concentration $\geq 10^{4} \mathrm{~cm}^{-3}$ with a maximum hourly $\mathrm{O}_{3}$ mixing ratio $\leq 90 \mathrm{ppbv}$ ), and (iv) (16 days): non-NPF events on non- $\mathrm{O}_{3}$ episode days with low $\mathrm{PN}$ concentrations (PN concentration $\leq 10^{4} \mathrm{~cm}^{-3}$ ). The hourly average $\mathrm{O}_{3}$ mixing ratio, nucleation mode particle and total PN concentrations in the size range of 5.5-350 $\mathrm{nm}$ from 08:00 to 16:00 LT were higher on most NPF event days (Type i) than on non-NPF event days with $\mathrm{O}_{3}$ episodes (Type ii). Different from Types $\mathrm{i}$ and ii events, the elevated PN concentration in Type iii events was probably attributed to primary emissions from local sources, i.e. vehicle emissions. The detailed discussion is shown in Sect. 3.2.

\subsection{Comparison of NPF days and non-NPF days}

To find out the favorable conditions for the NPF events, comparison of different parameters (i.e. meteorological conditions and gas phase concentrations) between NPF days and non-NPF days was made. Here the non-NPF days included non-NPF events on $\mathrm{O}_{3}$ episode days (Type ii), and on non$\mathrm{O}_{3}$ episode days with both high and low PN concentrations (Types iii and iv). Figure 2 shows the average diurnal variations of total $\mathrm{PN}$ concentration, $\mathrm{SO}_{2}, \mathrm{NO}_{\mathrm{x}}, \mathrm{CO}, \mathrm{O}_{3}$ and meteorological conditions (solar radiation, $\mathrm{RH}, T$ and wind rose plots) during NPF event days and non-NPF event days over the whole sampling period at TMS, respectively. 
Table 1. Summary of the observed formation start time, the hourly average mixing ratios of trace gases $\left(\mathrm{SO}_{2}, \mathrm{NO}_{\mathrm{x}}, \mathrm{CO}\right.$ and $\left.\mathrm{O}_{3}\right)$, meteorological conditions (UV, $T, \mathrm{RH}$ and wind), total PN concentration $(5.5-350 \mathrm{~nm})$ and nucleation mode particle concentration $\left(N_{\text {nuc }}\right)$ in four different types of events classified from NPF event days (class Ia, Ib and II events) and non-NPF event days from 08:00 to 16:00 LT observed at TMS.

\begin{tabular}{|c|c|c|c|c|c|c|c|c|c|c|c|c|}
\hline Event type & Date & $\begin{array}{l}\text { Observed } \\
\text { NPF start } \\
\text { time (LT) }\end{array}$ & $\begin{array}{c}\mathrm{O}_{3} \\
(\mathrm{ppb})\end{array}$ & $\begin{array}{c}\mathrm{SO}_{2} \\
(\mathrm{ppb})\end{array}$ & $\begin{array}{l}\mathrm{NO}_{2} \\
(\mathrm{ppb})\end{array}$ & $\begin{array}{c}\mathrm{NO} \\
(\mathrm{ppb})\end{array}$ & $\begin{array}{c}\mathrm{CO} \\
(\mathrm{ppb})\end{array}$ & $\begin{array}{c}\text { Solar } \\
\text { radiation } \\
\left(\mathrm{W} \mathrm{m}^{-2}\right)\end{array}$ & $\begin{array}{c}\text { Relative } \\
\text { humidity } \\
(\%)\end{array}$ & $\begin{array}{c}\text { Temperature } \\
\left({ }^{\circ} \mathrm{C}\right)\end{array}$ & $\begin{array}{l}\text { Wind speed/ } \\
\text { direction } \\
\left(\mathrm{m} \mathrm{s}^{-1} /{ }^{\circ}\right)\end{array}$ & $\begin{array}{l}\text { Total PN/ } N_{\text {nu }} \\
\text { concentration } \\
\left(\mathrm{cm}^{-3} \times 10^{4}\right)\end{array}$ \\
\hline \multirow{12}{*}{$\begin{array}{l}\text { Type i } \\
\left(\mathrm{NPF}+\mathrm{O}_{3}\right) \\
\text { Day }\end{array}$} & 27 Oct 2010 (Class Ia) & 11:00 & 62.5 & 3.9 & 8.1 & 4.0 & 406 & 522 & 75.6 & 14.6 & $3.5 / 332$ & $1.92 / 0.60$ \\
\hline & 28 Oct 2010 (Class Ia) & $10: 00$ & 67.5 & 4.3 & 8.2 & 3.9 & 400 & 561 & 62.5 & 13.7 & $3.5 / 337$ & $2.76 / 1.1$ \\
\hline & 29 Oct 2010 (Class Ia) & $10: 30$ & 79.1 & 5.7 & 9.5 & 3.8 & 476 & 546 & 61.5 & 14.8 & $2.6 / 302$ & $2.07 / 0.52$ \\
\hline & 30 Oct 2010 (Class Ib) & $10: 45$ & 86.6 & 8.2 & 9.2 & 3.5 & 599 & 546 & 56.1 & 15.1 & $2.8 / 310$ & $1.65 / 0.58$ \\
\hline & 31 Oct 2010 (Class II) & $10: 20$ & 84.6 & 5.0 & 10.2 & 3.6 & 557 & 539 & 69.5 & 17.0 & $2.0 / 336$ & $1.01 / 0.10$ \\
\hline & 1 Nov 2010 (Class Ia) & $10: 15$ & 87.1 & 4.7 & 8.1 & 3.5 & 494 & 565 & 62.7 & 18.0 & $1.1 / 330$ & $1.55 / 0.50$ \\
\hline & 2 Nov 2010 (Class Ib) & $10: 15$ & 93.1 & 5.1 & 8.2 & 3.5 & 551 & 548 & 64.7 & 18.0 & $1.7 / 301$ & $0.76 / 0.15$ \\
\hline & 8 Nov 2010 (Class Ib) & $10: 30$ & 88.4 & 4.5 & 10.2 & 3.7 & 526 & 528 & 59.0 & 20.4 & $2.0 / 315$ & $1.42 / 0.11$ \\
\hline & 9 Nov 2010 (Class Ib) & $10: 35$ & 88.9 & 5.6 & 8.4 & 3.6 & 518 & 515 & 53.9 & 18.9 & $1.3 / 332$ & $1.18 / 0.16$ \\
\hline & 11 Nov 2010 (Class II) & 11:00 & 91.4 & 3.7 & 11.1 & 3.7 & 434 & 513 & 39.0 & 20.0 & $1.5 / 341$ & $0.92 / 0.15$ \\
\hline & 12 Nov 2010 (Class II) & $10: 30$ & 77.4 & 5.3 & 6.5 & 3.7 & 428 & 525 & 47.0 & 20.1 & $0.82 / 52$ & $0.87 / 0.17$ \\
\hline & 26 Nov 2010 (Class II) & $10: 45$ & 74.5 & 5.0 & 7.9 & 3.5 & 487 & 424 & 66.1 & 16.5 & $1.0 / 48$ & $0.72 / 0.054$ \\
\hline \multirow{4}{*}{$\begin{array}{l}\text { Type ii } \\
(\text { Non-NPF + } \\
\left.\mathrm{O}_{3}\right) \text { Day }\end{array}$} & 17 Nov 2010 & - & 77.8 & 4.4 & 10.6 & 4.0 & 639 & 451 & 80.5 & 17.5 & $1.5 / 334$ & $0.65 / 0.010$ \\
\hline & 18 Nov 2010 & - & 75.5 & 3.7 & 12.2 & 3.7 & 529 & 360 & 81.9 & 18.0 & $1.3 / 330$ & $0.67 / 0.012$ \\
\hline & 19 Nov 2010 & - & 78.6 & 5.0 & 12.8 & 3.7 & 694 & 424 & 81.5 & 18.3 & $1.4 / 331$ & $0.78 / 0.018$ \\
\hline & 27 Nov 2010 & - & 72.8 & 4.7 & 7.6 & 3.5 & 480 & 355 & 74.0 & 17.4 & $2.2 / 85$ & $0.37 / 0.030$ \\
\hline \multirow{3}{*}{$\begin{array}{l}\text { Type iii } \\
(\text { Non-NPF + } \\
\text { non-O } 3+ \\
\text { high PN) Day }\end{array}$} & 7 Nov 2010 & - & 56.0 & 6.7 & 20.3 & 4.2 & 718 & 424 & 79.2 & 20.6 & $0.42 / 267$ & $0.97 / 0.024$ \\
\hline & 21 Nov 2010 & - & 37.5 & 6.3 & 21.5 & 5.2 & 453 & 327 & 85.4 & 19.1 & $0.32 / 220$ & $1.0 / 0.034$ \\
\hline & 29 Nov 2010 & - & 51.1 & 8.6 & 31.4 & 8.0 & 578 & 230 & 87.0 & 18.3 & $0.44 / 288$ & $0.99 / 0.013$ \\
\hline $\begin{array}{l}\text { Type iv } \\
(\text { Non-NPF }+ \\
\text { non- } \mathrm{O}_{3}+ \\
\text { low PN) Day }\end{array}$ & Other 16 days & - & 58.6 & 3.4 & 16.8 & 4.5 & 467 & 291 & 78.3 & 18.0 & $1.9 / 78$ & $0.56 / 0.011$ \\
\hline
\end{tabular}

\subsubsection{Particle number concentration and diurnal variation}

It was found that the diurnal pattern of PN concentration was different between NPF events and non-NPF events (Fig. 2). In NPF events, the PN concentration began to rise at 10:00 $\left(0.72 \times 10^{4} \mathrm{~cm}^{-3}\right)$, reached its peak at 14:00 $\left(1.5 \times 10^{4} \mathrm{~cm}^{-3}\right)$, and then gradually decreased, similar to the diurnal pattern of $\mathrm{O}_{3}$. In non-NPF events, the PN concentration showed a slow increase from 10:00, reached the peak value at 16:00 $\left(\sim 0.85 \times 10^{4} \mathrm{~cm}^{-3}\right)$, and then decreased. The peak value of $\mathrm{PN}$ coincided with peaks of $\mathrm{NO}_{\mathrm{x}}$ and $\mathrm{SO}_{2}$, indicating the influence of primary emissions from urban area on non-NPF days, especially for nonNPF events on high PN concentration days. As expected, the 24-h average total PN concentration was significantly higher in NPF events $\left(0.95 \pm 0.13 \times 10^{4} \mathrm{~cm}^{-3}\right)$ than that $\left(0.50 \pm 0.06 \times 10^{4} \mathrm{~cm}^{-3}\right)$ in non-NPF events $(p<0.001)$. The PN values observed in this study were slightly lower than those reported at a site in the Po Valley area, Italy (Hamed et al., 2007), where the maximum total PN concentrations on NPF event days and non-NPF event days were $2.4 \times 10^{4} \mathrm{~cm}^{-3}$ and $(0.7-1.5) \times 10^{4} \mathrm{~cm}^{-3}$, respectively, in the same season. However, at another site in the Po Valley, the average $\mathrm{PN}$ concentration for $5-800 \mathrm{~nm}$ particles during the NPF events was about $1 \times 10^{4} \mathrm{~cm}^{-3}$ with a range of $0.2 \times 10^{4}$ to $2 \times 10^{4} \mathrm{~cm}^{-3}$ (Rodriguez et al., 2005), sim- ilar to the levels found in this study. In Pittsburgh, the average PN concentration for $3-500 \mathrm{~nm}$ particles was about $2.2 \times 10^{4} \mathrm{~cm}^{-3}$ (Stanier et al., 2004b), a little higher than the observed values at TMS.

\subsubsection{Effect of meteorological parameters on new particle formation}

In this study, the maximum solar radiation on NPF event days $\left(750 \mathrm{~W} \mathrm{~m}^{-2}\right)$ was $50 \%$ higher than that $\left(500 \mathrm{~W} \mathrm{~m}^{-2}\right)$ on non-NPF event days (Fig. 2), suggesting the association between solar radiation and NPF events. Indeed, all NPF events were initiated at about 10:00-11:00 when the solar radiation rapidly increased. This could be explained by the fact that photochemical reactions among various chemicals were facilitated by stronger solar radiation, leading to NPF events. The observations are consistent with other studies (Stanier et al., 2004b; Hamed et al., 2007; Guo et al., 2008; Modini et al., 2009). Stanier et al. (2004b) claimed that nucleation was typically observed starting around 09:00 EST in Pittsburgh, USA. In eastern Australia, the NPF events usually began at 10:00-11:00 LT (Guo et al., 2008; Modini et al., 2009), except for one case in which a particularly strong nucleation event began in early morning (08:00) (Modini et al., 2009). In this study, the observed start time of NPF events was defined as the time when the $5.5 \mathrm{~nm}$ size particle concentration (the minimum detectable size for our aerosol instrument) 

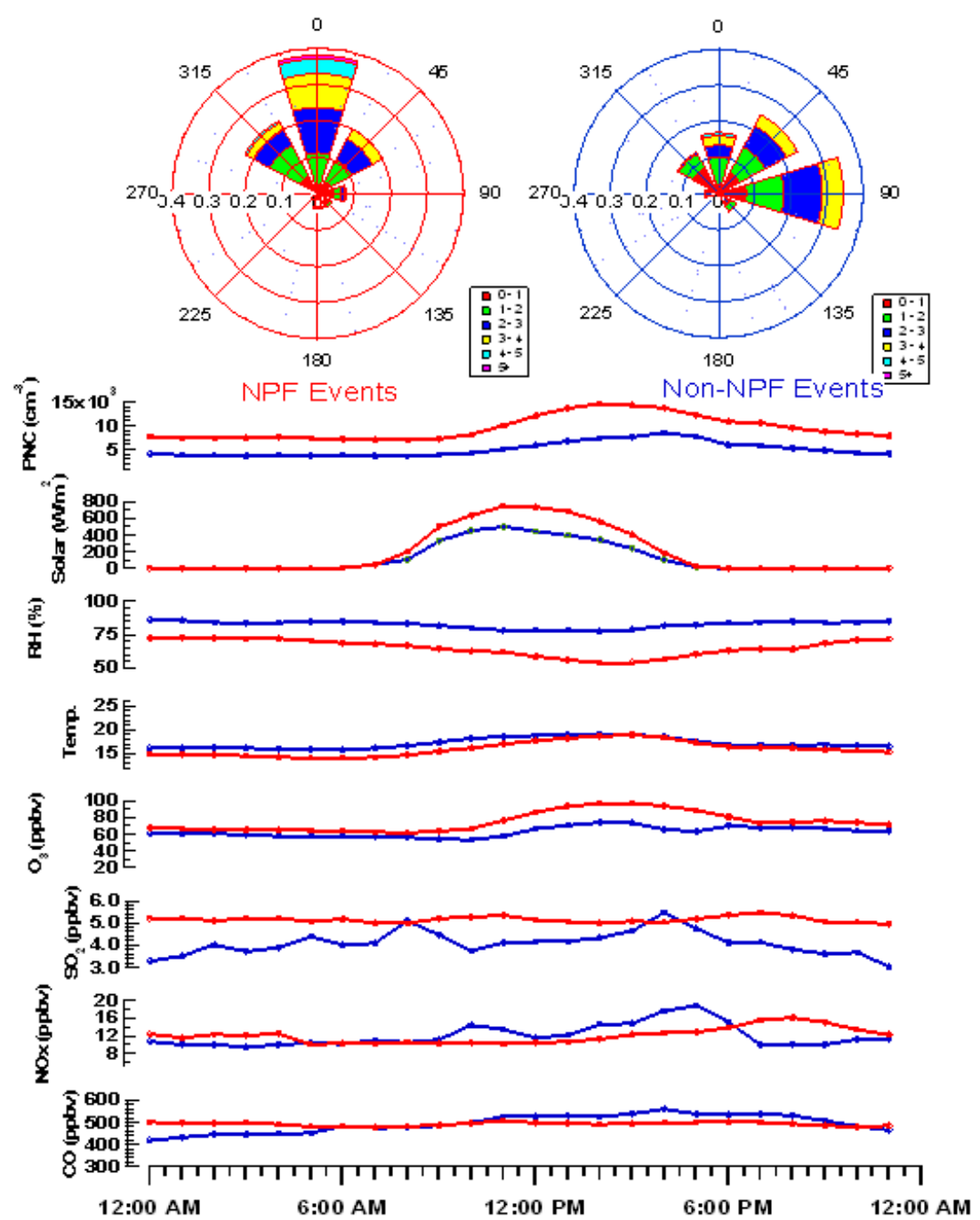

Fig. 2. Average diurnal variations of total $\mathrm{PN}$ concentration, trace gases $\left(\mathrm{SO}_{2}, \mathrm{NO}_{\mathrm{x}}, \mathrm{CO}\right.$ and $\left.\mathrm{O}_{3}\right)$ and meteorological conditions (solar radiation, RH, $T$ and wind) during NPF event days and non-NPF event days over the whole sampling period at the TMS site.

remarkably increased. Since it takes time for newly formed particles (about $1 \mathrm{~nm}$ in diameter) to grow into $5.5 \mathrm{~nm}$, the real start time of these NPF events could be earlier than the observed start time, and the time lag varies under different atmospheric conditions. The fitted time lag was defined in this study using the time series of the formation rate of $5.5 \mathrm{~nm}$ particles and the sulfuric acid concentration in each NPF event (Riipinen et al., 2011) (see Table 2). Based on the observed start time and the fitted time lag for each NPF event, the estimated start time of these NPF events were ranged from 09:50 to 10:40 LT during this sampling session.

Interestingly, the average temperature was slightly lower in the NPF events than that in the non-NPF events (Fig. 2), similar to those observed at different locations in Finland (Boy and Kulmala, 2002; Komppula et al., 2003; Vehkamäki et al., 2004) and in summer in Italy (Hamed et al., 2007). Contrarily, higher temperatures have been associated with the nucleation events in east and south Germany (Birmili and Wiednsohler, 2000; Birmili et al., 2003), and in spring, autumn and winter in Italy (Hamed et al., 2007). By investigating the fraction of GR explained by maximum sulfuric acid condensation in this study (detailed in Sect. 3.3.2), higher fractions (21-57\%) of sulfuric acid contribution to GR was found in the NPF events at lower temperature $\left(13.7-18^{\circ} \mathrm{C}\right)$, while lower fractions (9.2-22\%) was determined in the NPF events with higher temperature $\left(18.9-20.4^{\circ} \mathrm{C}\right)$, in line with the findings of Kurtén et al. (2007) who found that in the atmosphere, the majority of sulfuric acid molecules prefer to bind with water molecules under low temperature conditions. The result suggests that the lower temperature at the start time of the NPF events may enhance the nucleation of sulfuric acid with water vapor.

The RH on average was lower on NPF event days than on non-NPF event days (Fig. 2). Low RH, frequently down to 
Table 2. Particle formation rate $\left(J_{5.5}\right)$, growth rate $(\mathrm{GR})$, minimum and maximum condensation sink $(\mathrm{CS})$, sulfuric acid (SA) vapor concentration (Csa), the SA vapor needed for $1 \mathrm{~nm} \mathrm{~h}^{-1}$ particle size growth (Co), fractional contribution of SA vapor to particle growth (FC), fitted time delay $(\Delta t)$ and the exponent $\left(n_{J_{5.5}}\right)$ for the correlation of $J_{5.5}$ with sulfuric acid for each NPF event day covering 06:00-18:00 LT with p-value of the t-test.

\begin{tabular}{|c|c|c|c|c|c|c|c|c|c|}
\hline Date & $\begin{array}{c}J_{5.5} \\
\left(\mathrm{~cm}^{-3} \mathrm{~s}^{-1}\right)\end{array}$ & $\begin{array}{c}\mathrm{GR} \\
\left(\mathrm{nm} \mathrm{h}^{-1}\right)\end{array}$ & $\begin{array}{c}\mathrm{CS} \\
\left(\mathrm{s}^{-1}\right)\end{array}$ & $\begin{array}{c}\text { Csa } \\
\left(\times 10^{6} \mathrm{~cm}^{-3}\right)\end{array}$ & $\begin{array}{r}\text { Co } \\
\left(\times 10^{6} \mathrm{~cm}^{-3}\right)\end{array}$ & $\begin{array}{l}\mathrm{FC} \\
(\%)\end{array}$ & $\begin{array}{l}\Delta t \\
(\mathrm{~h})\end{array}$ & $n_{J_{5.5}}$ & $\begin{array}{l}R \\
\text { p-value }\end{array}$ \\
\hline \multicolumn{10}{|l|}{ Class Ia } \\
\hline 27 Oct 2010 & 5.9 & 5.4 & $0.021-0.062$ & 12.3 & 10.7 & 21.3 & 0.4 & 1.0 & $0.60, p<0.05$ \\
\hline 28 Oct 2010 & 6.9 & 3.0 & $0.021-0.053$ & 12.5 & 11.0 & 37.9 & 0.8 & 1.1 & $0.70, p<0.001$ \\
\hline 29 Oct 2010 & 3.6 & 4.0 & $0.025-0.062$ & 11.7 & 11.0 & 26.6 & 0.2 & 1.0 & $0.61, p<0.05$ \\
\hline 1 Nov 2010 & 6.0 & 5.0 & $0.023-0.033$ & 7.77 & 10.9 & 14.3 & 0.4 & 1.3 & $0.77, p<0.01$ \\
\hline \multicolumn{10}{|l|}{ Class Ib } \\
\hline 30 Oct 2010 & 2.6 & 1.5 & $0.031-0.055$ & 9.40 & 11.1 & 56.5 & 0.4 & 1.1 & $0.69, p<0.05$ \\
\hline 2 Nov 2010 & 1.8 & 2.7 & $0.021-0.024$ & 9.72 & 10.9 & 33.0 & 0.6 & 1.4 & $0.77, p<0.05$ \\
\hline 8 Nov 2010 & 1.7 & 4.5 & $0.018-0.046$ & 9.14 & 11.0 & 18.5 & 0.2 & 1.0 & $0.72, p<0.05$ \\
\hline 9 Nov 2010 & 2.2 & 3.0 & $0.014-0.026$ & 7.52 & 11.4 & 22.0 & 0.2 & 1.2 & $0.73, p<0.01$ \\
\hline \multicolumn{10}{|l|}{ Class II } \\
\hline 31 Oct 2010 & 1.1 & 1.8 & $0.024-0.030$ & 8.92 & 11.0 & 45.1 & 0.6 & 1.1 & $0.74, p<0.05$ \\
\hline 11 Nov 2010 & 1.5 & 8.4 & $0.008-0.041$ & 8.76 & 11.3 & 9.2 & 0.4 & 1.1 & $0.69, p<0.05$ \\
\hline 12 Nov 2010 & 1.0 & 4.6 & $0.016-0.031$ & 6.20 & 12.0 & 11.2 & 0.2 & 1.2 & $0.78, p<0.01$ \\
\hline 26 Nov 2010 & 1.0 & 2.4 & $0.010-0.024$ & 6.09 & 10.8 & 23.5 & 0.4 & 1.3 & $0.49, p<0.05$ \\
\hline
\end{tabular}

near $50 \%$ (at noon hours), was observed during nucleation events, similar to the RH levels in the Po Valley area, Italy (Hamed et al., 2007), and in clean areas in Hyytiälä station, Finland (Boy and Kulmala, 2002). This is a strong indication that the NPF is favored under low RH. This could be partly explained by the fact that lower RH days usually have less clouds causing more solar radiation and subsequently producing more $\mathrm{OH}$ radicals to form more condensable vapors (Hamed et al., 2007). Another possible reason could be that at high RH, condensation sink increased due to hygroscopic growth of the pre-existing particles, which inhibited the nucleation (Hamed et al., 2011).

During the NPF event days, the wind was mainly from the north direction, while east winds were more frequently observed on the non-NPF event days (Fig. 2). To investigate the transport pathways of the air masses arriving at the TMS site during the sampling period, we analyzed back trajectories for NPF days and non-NPF days. The analysis was done by using HYSPLIT 4 (Hybrid Single-Particle Lagrangian Integrated Trajectory) model developed by NOAA Air Resource Laboratory (ARL) (Draxler and Hess, 1998). Back trajectories arriving at 10:00 with $1000 \mathrm{~m}$ arrival height were calculated one day backward in time. Figure S2 shows the position of the air parcel at 24-h back in time for NPF and non-NPF days, respectively. The air masses were classified into three major categories on the NPF days: (i) air masses originated from inland China (track 1, accounting for $56 \%$ of the total trajectories); (ii) air masses originated from Yangtze River Delta with a faster movement than track 1 (track 2, 32\%); and (iii) air masses originated from the South China Sea with a very slow movement (track 3, $12 \%)$. The track 1 mainly occurred at daytime hours on $\mathrm{NPF}$ event days, and the average mixing ratios of $\mathrm{SO}_{2}, \mathrm{O}_{3}$, $\mathrm{CO}$ and $N_{\text {nuc }}$ concentrations at TMS were $4.9 \mathrm{ppbv}, 87 \mathrm{ppbv}$, $480 \mathrm{ppbv}$ and $0.52 \times 10^{4} \mathrm{~cm}^{-3}$, respectively. The air in track 1 had the highest $\mathrm{O}_{3}$ mixing ratio and $N_{\text {nuc }}$ concentration, followed by the air in track 3 ( 74 ppbv for $\mathrm{O}_{3}, p<0.001$ and $0.36 \times 10^{4} \mathrm{~cm}^{-3}$ for $\left.N_{\text {nuc }}, p<0.05\right)$ and air in track 2 (66 ppbv for $\mathrm{O}_{3}, p<0.001$ and $0.17 \times 10^{4} \mathrm{~cm}^{-3}$ for $N_{\text {nuc }}$, $p<0.001$ ), indicating that air masses originated from track 1 were favorable to the NPF events. On the other hand, there were two types of air masses classified on non-NPF days: (i) track 1 originated from eastern China coast with a slow movement, accounting for $92 \%$ of the total air masses; and (ii) track 2 originated from western Pacific Ocean and arrived at TMS with a much faster movement, accounting for $8 \%$ of the total air masses. The average mixing ratios of $\mathrm{SO}_{2}$, $\mathrm{O}_{3}$ and $N_{\text {nuc }}$ concentration in track 1 were $4.0 \mathrm{ppbv}, 87 \mathrm{ppbv}$, and $0.05 \times 10^{4} \mathrm{~cm}^{-3}$, respectively, while they were $3.6 \mathrm{ppbv}$, $56 \mathrm{ppbv}$, and $0.02 \times 10^{4} \mathrm{~cm}^{-3}$, respectively in track 2 . The higher $\mathrm{O}_{3}(87 \mathrm{ppbv})$ and $\mathrm{CO}(640 \mathrm{ppbv})$ values in track 1 air were mainly due to regional transport from eastern China. In contrast, low $\mathrm{SO}_{2}$ (3.6 ppbv), $\mathrm{CO}$ (421 ppbv), $\mathrm{O}_{3}$ (56 ppbv) and high $\mathrm{RH}(83 \%)$ levels in track 2 were caused by the strong winds originated from western Pacific Ocean, which brought clean marine air and scattered rain to the sampling site. The back trajectory results are consistent with the rose plot analysis which found that air masses associated with 
NPF events were mainly from northwestern to northeastern directions.

\subsubsection{Effect of gas concentrations on new particle formation}

The hourly average $\mathrm{O}_{3}$ mixing ratios were higher on NPF event days than the corresponding values on non-NPF event days during daytime hours (i.e. 10:00-18:00 LT) (Fig. 2). Also, the diurnal pattern of $\mathrm{O}_{3}$ mixing ratio was consistent with that of PN concentration on the NPF event days, suggesting that $\mathrm{O}_{3}$ and NPF had similar sources or formation mechanisms, most likely the photochemical reactions among the precursors (i.e. VOCs, $\mathrm{NO}_{\mathrm{x}}$ and $\mathrm{SO}_{2}$ ) of $\mathrm{O}_{3}$ and NPF. As such, $\mathrm{O}_{3}$ could also be an important indicator for nucleation event occurrences. In addition, $\mathrm{O}_{3}$ could be the precursor of $\mathrm{NPF}$ as it is responsible for the formation of condensable species via direct reactions with VOCs, and indirect generation of other oxidants (i.e. $\mathrm{OH}$ and $\mathrm{HO}_{2}$ ) upon photolysis.

All the hourly average $\mathrm{SO}_{2}$ mixing ratios were higher on the NPF event days than on the non-NPF event days, except for the values at 08:00 LT and 16:00 LT, which were likely related to primary emissions. The average mixing ratio on NPF event days and non-NPF event days was $5.2 \pm 0.2 \mathrm{ppbv}$ and $4.2 \pm 2.5 \mathrm{ppbv}$, respectively. The large variations of the $\mathrm{SO}_{2}$ mixing ratio on non-NPF event days were caused by some high $\mathrm{SO}_{2}$ levels observed on non-NPF days with high PN concentrations (Type iii) (Table 1), due to regional transport and/or local emissions. When the non-NPF days with high PN concentrations (Type iii) were excluded from the total non-NPF event days, the average $\mathrm{SO}_{2}$ mixing ratio on nonNPF days became $4.2 \pm 0.4 \mathrm{ppbv}$, lower than that on the NPF event days. For NPF events, $\mathrm{SO}_{2}$ is needed for the production of sulfuric acid, which participates in the nucleation and growth of stable nm-sized clusters. The higher $\mathrm{SO}_{2}$ found in the NPF events implied that $\mathrm{SO}_{2}$ might be favorable to the nucleation. However, by comparing the $\mathrm{SO}_{2}$ levels in the NPF events (Type i) with those in the non-NPF events with high PN concentrations (Type iii), we found that the average $\mathrm{SO}_{2}$ mixing ratio in non-NPF events with high PN concentration (Type iii) was higher than that in NPF events (Type i) (Table $1, p<0.05$ ), indicating that only a high $\mathrm{SO}_{2}$ level was not sufficient for NPF. Other factors such as less pre-existing large particles and strong solar radiations (see Table 1) were also required.

It was found that the average daytime $\mathrm{NO}_{\mathrm{x}}$ value $(11 \pm$ $1.3 \mathrm{ppbv}$, daytime $\mathrm{NO}_{2}: 7.1 \pm 0.8 \mathrm{ppbv}$ ) was lower on NPF event days than that $\left(14 \pm 1.6 \mathrm{ppbv}\right.$, daytime $\mathrm{NO}_{2}: 9.2 \pm$ 1.5 ppbv, $p<0.001$ ) on non-NPF event days during the process of formation and growth (Fig. 2). The stronger solar radiation on NPF event days than on non-NPF event days was probably one of the reasons for the lower $\mathrm{NO}_{2}$ levels on the NPF event days. The increase in solar radiation would promote the decay of $\mathrm{NO}_{2}$ mixing ratios via the complex photochemical reactions, consistent with the negative correlation
( $R=-0.86, p<0.001)$ between the daytime $\mathrm{NO}_{2}$ values and solar radiation on the NPF event days. On non-NPF event days, the daytime $\mathrm{NO}_{2}$ mixing ratios were higher than the corresponding hourly values on the NPF event days, and had a peak at 18:00 LT, suggesting the possible influence of primary emissions transported to the site from the region and/or local urban areas via mesoscale recirculation.

\subsection{Characteristics of new particle formation and growth}

Table 2 shows the formation rate, growth rate and condensation sink of each NPF and growth event observed at TMS. The correlations of particle formation rate, growth rate and condensation sink with meteorological parameters, inorganic trace gas concentrations $\left(\mathrm{O}_{3}, \mathrm{SO}_{2}, \mathrm{NO}_{\mathrm{x}}\right.$ and $\left.\mathrm{CO}\right)$, biogenic VOCs (BVOCs), anthropogenic VOCs (AVOCs), and carbonyl compounds are presented in Table 3 . The correlations of sulfuric acid and the VOC oxidation products with the formation rate and growth rate for each NPF event were particularly investigated in this section.

In this study, the formation rate (FR) at $5.5 \mathrm{~nm}$ was estimated from the increase of 5.5-10 nm PN concentration between the event start time and the time when the PN concentration exhibited a maximum during the NPF event. Based on the calculations, the FR values varied between 0.044 and $10.2 \mathrm{~cm}^{-3} \mathrm{~s}^{-1}$. The estimated average FR for Class Ia event was about $5.6 \mathrm{~cm}^{-3} \mathrm{~s}^{-1}$, higher than that of Class $\mathrm{Ib}$ $\left(4.2 \mathrm{~cm}^{-3} \mathrm{~s}^{-1}\right)$ and Class II $\left(1.1 \mathrm{~cm}^{-3} \mathrm{~s}^{-1}\right)$, indicating high FRs of nucleation mode particles in rural areas like the TMS site. The average growth rate (GR) for the nucleation events was calculated by the slope of GMD against time during the period of particle growth from 5.5 to $25 \mathrm{~nm}$. By computation, the GRs of Class Ia events observed at TMS were from 3.0 to $5.4 \mathrm{~nm} \mathrm{~h}^{-1}$ (average $4.4 \mathrm{~nm} \mathrm{~h}^{-1}$ ), while the GRs of Class Ib events ranged from 1.5 to $4.5 \mathrm{~nm} \mathrm{~h}^{-1}$ (average $2.9 \mathrm{~nm} \mathrm{~h}^{-1}$ ), and from 1.8 to $8.4 \mathrm{~nm} \mathrm{~h}^{-1}$ (average $4.3 \mathrm{~nm} \mathrm{~h}^{-1}$ ) for Class II events, all in line with the range of new particle growth rates observed in rural/suburban locations i.e. $1-10 \mathrm{~nm} \mathrm{~h}^{-1}$ (Kulmala et al., 2004a).

\subsubsection{Case study-typical new particle formation and growth event at TMS}

In order to give a visible picture of NPF and growth processes from the beginning to the end, one Class Ia NPF event intensively occurred on 28 October 2010 was selected for the case study. New particle formation event (nucleation mode) on 28 October was clearly observed after raining on 27 October, in line with the fact that nucleation events often occur after a sharp decrease in concentrations of pre-existing particles with large surface area (Guo et al., 2008; Liu et al., 2008). The minimum temperature of 12.5 degrees recorded on 28 October was the lowest in October since 1988. The NFP started when the wind speed increased to a maximum 
Table 3. Linear correlations of gaseous pollutants, metrological parameters, CS, BVOCs, AVOCs and carbonyls with the FR, GR and CS for all NPF events observed during the sampling campaign. The data points for gaseous pollutants, metrological parameters and CS are 72; for VOCs and carbonyls are 32. The p-values for all the correlations are below 0.05 .

\begin{tabular}{|c|c|c|c|c|c|c|c|c|c|c|c|c|c|c|c|}
\hline \multirow[b]{2}{*}{ Parameter } & \multicolumn{4}{|c|}{ Gaseous pollutants } & \multicolumn{3}{|c|}{ Metrological parameters } & \multirow{2}{*}{\begin{tabular}{r|}
$\mathrm{CS}$ \\
$R$ \\
$(\mathrm{CS})$
\end{tabular}} & \multicolumn{3}{|c|}{ BVOCs } & \multirow{2}{*}{$\begin{array}{r}\text { AVOC } \\
R \\
\text { (Aro- } \\
\text { matics) }\end{array}$} & \multicolumn{3}{|c|}{ Carbonyls } \\
\hline & $\begin{array}{r}R \\
\left(\mathrm{O}_{3}\right)\end{array}$ & $\begin{array}{r}R \\
\left(\mathrm{SO}_{2}\right)\end{array}$ & $\begin{array}{r}R \\
\left(\mathrm{NO}_{\mathrm{x}}\right)\end{array}$ & $\begin{array}{r}R \\
(\mathrm{CO})\end{array}$ & $\begin{array}{c}R \\
\text { (Radia- } \\
\text { tion) }\end{array}$ & $\begin{array}{r}R \\
(\mathrm{RH})\end{array}$ & $\begin{array}{r}R \\
(T)\end{array}$ & & $\begin{array}{r}R \\
\text { (Isoprene) }\end{array}$ & $\begin{array}{c}R \\
\text { (Mono- } \\
\text { terpenes) }\end{array}$ & $\begin{array}{c}R \\
\left(\left[\mathrm{MT}^{*}\right.\right. \\
\left.\left.\mathrm{O}_{3}\right]\right)\end{array}$ & & $\begin{array}{r}R \\
\text { (Form- } \\
\text { aldehyde) }\end{array}$ & $\begin{array}{r}R \\
\text { (Acet- } \\
\text { aldehyde) }\end{array}$ & $\begin{array}{r}R \\
\text { (Ace- } \\
\text { tone) }\end{array}$ \\
\hline FR & -0.54 & 0.62 & -0.22 & -0.45 & 0.54 & -0.40 & -0.62 & -0.56 & -0.40 & 0.57 & 0.35 & -0.42 & -0.26 & -0.56 & -0.10 \\
\hline GR & 0.51 & -0.33 & -0.26 & -0.61 & 0.64 & -0.48 & 0.41 & 0.51 & -0.38 & 0.82 & 0.80 & -0.50 & -0.40 & -0.45 & -0.25 \\
\hline $\mathrm{CS}$ & -0.48 & 0.62 & 0.70 & 0.44 & 0.62 & 0.45 & -0.56 & - & 0.72 & 0.35 & 0.20 & 0.22 & -0.10 & 0.16 & 0.35 \\
\hline
\end{tabular}

* Monoterpenes include: $\alpha$-Pinene, $\beta$-Pinene, Myrcene and Limonene. Aromatics include: Benzene, Toluene, $m$-xylene, $p$-xylene, $o$-xylene, 2 -ethyltoluene, 3-ethyltoluene, 4-thyltoluene, 1,3,5-trimethylbenzene, 1,2,4-trimethylbenzene and 1,2,3-trimethylbenzene.

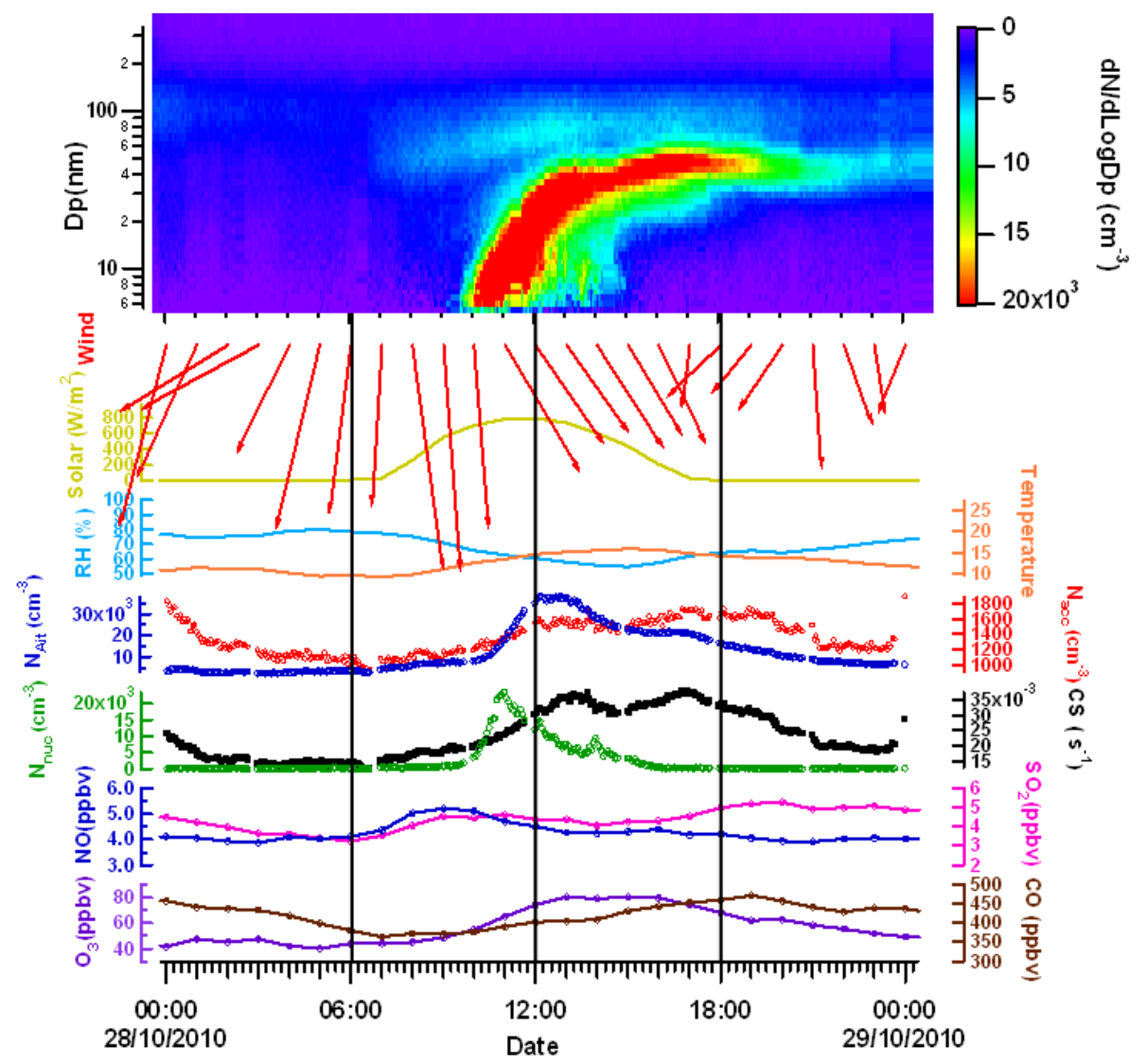

Fig. 3. Contour plots of the average diurnal variations of particle size distribution, the meteorological conditions and the concentrations of airborne pollutants on 28 October 2010 at TMS. From top to bottom, the parameters are: (i) Particle size distribution; (ii) Wind direction and speed (iii) Solar radiation; (iv) Temperature and relative humidity; (v) Number concentrations of Aitken mode and accumulation mode particles; (vi) Number concentration of nucleation mode particles and condensation sink, (vii) $\mathrm{NO}$ and $\mathrm{SO}_{2}$; (viii) $\mathrm{O}_{3}$ and CO.

value (i.e. $\left.5.26 \mathrm{~m} \mathrm{~s}^{-1}\right)(09: 00 \mathrm{LT})$. At the same time, slow increase in $\mathrm{SO}_{2}$, decrease in $\mathrm{CO}$ (see Fig. 3), and rise of the calculated boundary layer height were observed (Fig. S3), indicating that these variations accompanied with the NPF were likely a result of breakup of the morning inversion that mixed $\mathrm{SO}_{2}$-enriched and $\mathrm{CO}$-depleted air from aloft and diluted the accumulated urban emissions (Q. Zhang et al., 2004). As shown in Fig. 3, the nucleation mode appeared in the measurement range at about 10:00 LT and increased substan- tially with an observable growth rate $\left(3.0 \mathrm{~nm} \mathrm{~h}^{-1}\right)$. The nucleation mode particle concentration $\left(N_{\text {nuc }}\right)$ increased rapidly from $\sim 0.13 \times 10^{4} \mathrm{~cm}^{-3}$ to $\sim 2.4 \times 10^{4} \mathrm{~cm}^{-3}$ at noon with an average formation rate $\left(J_{5.5}\right)$ of $6.9 \mathrm{~cm}^{-3} \mathrm{~s}^{-1}$. Since the concentration of around $0.2-1 \times 10^{6} \mathrm{~cm}^{-3}$ of $<5 \mathrm{~nm}$ particles is needed to induce a growth rate of $1 \mathrm{~nm} \mathrm{~h}^{-1}$ by self-coagulation (Kulmala et al., 2004b), the initial nucleation mode particle concentration of $<3 \times 10^{4} \mathrm{~cm}^{-3}$ in this event indicated that self-coagulation only made a minor 
contribution to the particle growth. After 14:00, the GR decreased whereas the CS increased from 0.021 to $0.053 \mathrm{~s}^{-1}$, suggesting the increase in large surface area particles might have scavenged potential condensable vapors responsible for particle growth. After 16:00, the total PN concentration decreased gradually to the background at 22:00. Additionally, correlation of $N_{\text {nuc }}$ with secondary pollutant $\mathrm{O}_{3}(R=0.70$, $p<0.001)$ was much higher than that with primary pollutants i.e. $\mathrm{SO}_{2}(R=0.17, p<0.01), \mathrm{CO}(R=0.06, p<$ $0.01)$ and $\mathrm{NO}(R=0.23, p<0.01)$, suggesting that the NPF event was likely associated with the photochemical formation via VOC oxidation processes, rather than direct emissions from urban sources.

Given that the transformation from gas-phase pollutants to nucleation mode particles requires sufficient time, there may be a delay between the measured gaseous pollutants i.e. $\mathrm{SO}_{2}$ and the formation of nucleation mode particles. Indeed, a much better correlation between $\mathrm{H}_{2} \mathrm{SO}_{4}$ proxy and $J_{5.5}$ with 0.8-h time lag was found (see Table 2), suggesting the possible involvement of $\mathrm{H}_{2} \mathrm{SO}_{4}$ vapor or/and $\mathrm{SO}_{2}$ oxidation products in this nucleation event. More detailed discussion is given in Sect. 3.3.2.

The variations of organic aerosol precursors i.e. VOCs and carbonyls were preliminarily investigated on 28 October. The concentrations of BVOC and AVOC species i.e. the potential precursors of secondary organic aerosols (SOA), started to increase at $\sim 07: 00 \mathrm{LT}$, reached the maxima at $\sim 13: 00 \mathrm{LT}$ (i.e. BVOCs: isoprene $96 \mathrm{pptv}, \alpha$-pinene $24 \mathrm{pptv}, \beta$-pinene 6 pptv, myrcene 5 pptv and limonene 329 pptv; and AVOCs: propene $510 \mathrm{pptv}$, toluene $6079 \mathrm{pptv}$, ethyltoluenes $180 \mathrm{pptv}$ and triethylbenzenes $246 \mathrm{pptv}$ ). The start time for the increase in VOC species (07:00 LT) were about $3 \mathrm{~h}$ earlier than the time when the $5.5 \mathrm{~nm}$ nucleation mode particles started to increase (10:00 LT). It is noteworthy that there is a time delay before a VOC turns to condensable species that could promote particle to grow to the detectable size of $5.5 \mathrm{~nm}$ for the instrument. The delayed time depends on the production rate of the condensational vapor from VOCs and on the growth rate of the particle from cluster into $5.5 \mathrm{~nm}$. It is known that the oxidation products of BVOCs and AVOCs have a potential contribution to the NPF and growth (Griffin et al., 1999; Kulmala et al., 2004a; Hatch et al., 2011). In this event, it was found that the concentrations of the measured BVOCs versus $N_{\text {nuc }}$ showed a power-law relation with a power exponent between 1 and 3, similar to all other NPF events found in this study (see Fig. S4). The results suggest the association of BVOCs with the NPF. Indeed, direct evidence on the participation of organic vapors in the nucleation process has been obtained in laboratory experiments (e.g. R. Zhang et al., 2004) and field measurements (e.g. Paasonen et al., 2010). More detailed discussion about the characteristics of contribution of VOCs on the growth rate is given in Sect. 3.3.3.

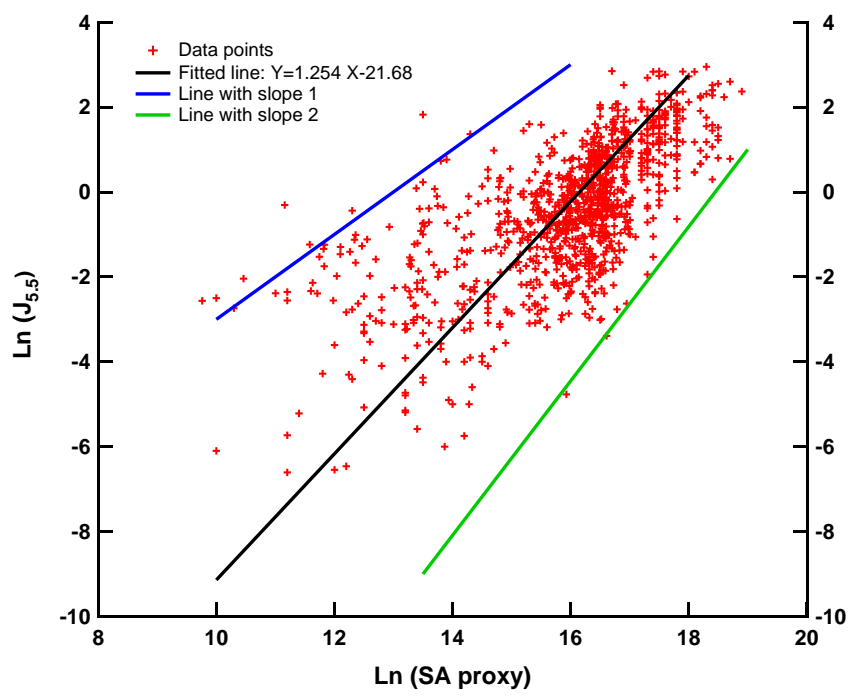

Fig. 4. The logarithm of formation rate $J_{5.5}$ estimated from particle measurements versus the logarithm of the sulfuric acid proxy (4 min averages) during the nucleation events from 06:00-16:00 LT. Sulfuric acid proxy concentrations have been delayed by the fitted time lags. Lines with slopes 1 and 2 (corresponding to values 1 and 2 in the exponent $n_{J_{5.5}}$ ) are also shown.

\subsubsection{Sulfuric acid vapor}

The real nucleation rate $\left(J_{\text {real }}\right)$ and the particle growth rate are both expected to be positively correlated with "nonvolatile" vapor concentrations (Kulmala et al., 2004). As already discussed in Sect. 3.2, we are unable to measure $J_{\text {real }}$ due to instrumental limitation. Nonetheless, it would be useful to study the relationship between measured gaseous compounds and the calculated $J_{5.5}$. In this study, $J_{5.5}$ had positive relationships with gas phase $\mathrm{SO}_{2}$ and solar radiation (Table 3). Since the product of ultraviolet radiation and $\mathrm{SO}_{2}$ (i.e. $\mathrm{UV} \times \mathrm{SO}_{2}$ ) can be used as a surrogate parameter for $\mathrm{H}_{2} \mathrm{SO}_{4}$ production (Petäjä et al., 2009), the positive relationships of $J_{5.5}$ with $\mathrm{SO}_{2}$ and solar radiation suggested that concentration of sulfuric acid had a contribution to the nucleation mode particle $(5.5 \mathrm{~nm})$ formation. Figure 4 shows a plot of the estimated particle formation rate $J_{5.5} \mathrm{vs}$. the sulfuric acid proxy calculated by Eq. (4) (in logarithmic scale). The sulfuric acid proxy concentrations here had been delayed by the fitted time lags for each NPF event ranging from 0.2-0.8 h. Moderate correlation coefficients $R$ ranging from 0.49 to 0.78 with all $p<0.05$ were observed (see Fig. 4 and Table 2). Several studies have analyzed the slope of $\log \left(\mathrm{H}_{2} \mathrm{SO}_{4}\right)$ vs. $\log \left(J_{3}\right)$ because this could in principle reveal the number of sulfuric acid molecules required for a critical, thermodynamically stable cluster as well as give hints on the acting nucleation mechanism. These studies have observed slopes between 1 and 2 (i.e. exponent $n_{J_{3}}$ between 1 and 2) (Weber et al., 1999; Kulmala et al., 2006; Sihto et al., 2006; Kuang et al., 2008). As shown in Fig. 4 and Table 2, the optimal fitted line had a 
slope of about 1.3 and the exponent $n_{J_{5.5}}$ for all NPF events never exceeded 2 in this study, indicating reasonable consistency with earlier studies. The results suggested that the activation of stable clusters and/or kinetic nucleation were possibly the mechanisms for atmospheric particle formation.

Apart from the connection with particle nucleation, the $\mathrm{H}_{2} \mathrm{SO}_{4}$ vapor has also been found to take part in the particle growth. Weber et al. (1997) estimated the growth rate of nucleation mode particles from the time taken between the increase in gas phase sulfuric acid concentration and the increase in $3 \mathrm{~nm}$ particle concentrations. The observed growth rates of $1-2 \mathrm{~nm} \mathrm{~h}^{-1}$ were approximately ten times faster than those calculated assuming condensational growth caused by sulfuric acid and water. In our calculations, we determined the observed growth rates from the SMPS data plots in the beginning of the event. Table 2 gives the fraction of sulfuric acid contribution to GR during each nucleation event, where the measured GR, estimated sulfuric acid concentration (Csa) and the sulfuric acid concentration needed for GR of $1 \mathrm{~nm} \mathrm{~h}^{-1}$ (Co) considering the influence of relative humidity (Nieminen et al., 2010) in each nucleation event are shown. The fraction contribution (FC) of sulfuric acid to GR in all NPF events ranged from 9.2 to $52.5 \%$, showing large variations of sulfuric acid contribution to the observed GR during these NPF event days. Meanwhile, no direct correlation between observed GR and sulfuric acid concentration was found, indicating that the condensation of sulfuric acid vapor for particle growth was influenced by the atmospheric conditions i.e. solar radiation, water vapor and background $\mathrm{PN}$ concentration.

To further investigate the key atmospheric conditions behind the nucleation events, we utilized the parameterization approach described by Stanier et al. (2004b), who suggested that favorable conditions for nucleation can be described using a product of UV radiation and sulfuric dioxide (its increase indicates increase of sulfuric acid concentration), and the condensation sink. Figure 5 shows scatter plot of $\mathrm{UV} \times \mathrm{SO}_{2}$ versus $\mathrm{CS}$ during the NPF events (red dots) and non-NPF events (blue dots) at TMS. For most of the NPF event days, the data points lay to the right of the diagonal line. The threshold (line) was calculated according to the modelbased correlations in Pirjola et al. (1999) under the groundlevel conditions. This model was designed to predict the required $\mathrm{H}_{2} \mathrm{SO}_{4}$ production rates for nucleation and growth as a function of CS, RH and temperature. The lower right region indicated more favorable conditions to nucleation than upper left region. As expected, the relatively low CS values on NPF days compared to those on non-NPF days were the favorable conditions for nucleation at this site. When the $\mathrm{UV} \times \mathrm{SO}_{2}$ product increased and the $\mathrm{CS}$ values decreased, the nucleation events were likely observed. The criterion of Stanier et al. (2004b) indicates that low enough CS value is needed together with high enough sulfuric acid production, in agreement with our findings that $\mathrm{SO}_{2}$, solar radiation and CS inverse have positive relationships with FR (Table 3).

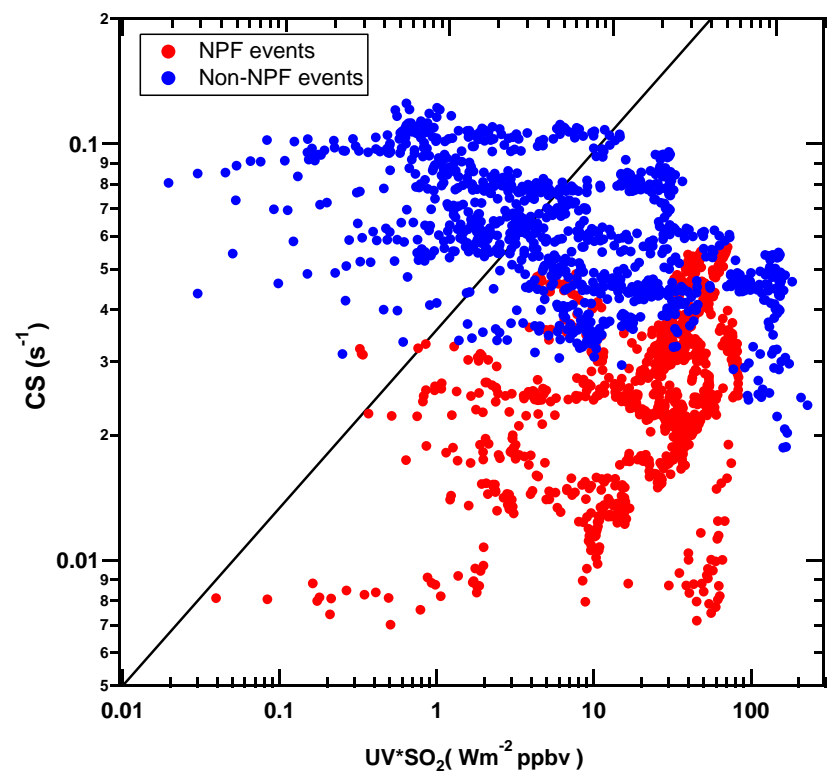

Fig. 5. Scatter plot of $\mathrm{UV} \times \mathrm{SO}_{2}$ versus condensation sink during the NPF events (red dots) and non-NPF events (blue dots). Condensational sink (y-axis-left) is plotted against the product of ultraviolet light intensity and $\mathrm{SO}_{2}$ concentration (x-axis). Four-minute averaged values are plotted from the event start time to the event end time on NPF event days. On non-NPF event days, a time range from 08:00 to 16:00 LT is applied.

At TMS, the NPF events occurred with $\mathrm{SO}_{2}$ mixing ratios ranged from 4.0-5.5 ppbv during the sampling period (October/November). Wang et al. (2005) reported that the monthly average mixing ratio of $\mathrm{SO}_{2}$ from August 2001 to December 2002 at a background site in Kong Hong was 7.5 ppbv in October and $11 \mathrm{ppbv}$ in November, respectively, suggesting that the $\mathrm{SO}_{2}$ background concentration in the PRD region was abundant for the required $\mathrm{SO}_{2}$ in nucleation events. Hence, low enough CS value and strong UV radiation are favorable conditions or even more important factors for NPF occurrence at this sampling site.

\subsubsection{VOCs}

Studies have demonstrated that many BVOC species, i.e. isoprene and monoterpenes, and some AVOCs such as toluene could make contributions to the formation of secondary organic aerosol in the atmosphere (e.g. Fu and Kawamura, 2011; Kamens et al., 2011). In this study, it was found that monoterpenes along with $\mathrm{O}_{3}$, solar radiation and temperature were positively correlated with GR, while other VOCs species, i.e. isoprene, aromatics and carbonyls including formaldehyde, acetaldehyde and acetone showed poor and negative relationships with GR (Table 3). However, the analysis on the correlations of isoprene with total PN concentrations and nucleation mode PN concentrations on NPF event days and non-NPF event days indicated that isoprene had 
linear correlations with PN and power-law correlations with $N_{\text {nuc }}$ on both NPF event days $\left(R_{\mathrm{PN}}=0.82\right.$ and $R_{N_{\text {nuc }}}=0.71$, $p<0.001)$ and on non-NPF event days $\left(R_{\mathrm{PN}}=0.70\right.$ and $\left.R_{N_{\text {nuc }}}=0.75, p<0.001\right)$, suggesting that isoprene might be not a critical parameter for NPF. Instead, the negative correlations of isoprene with FR $(R=-0.40, p<0.05)$ and GR ( $R=-0.38, p<0.05)$ implied that the increase in isoprene might have a negative effect on NPF. Indeed, a recent chamber study found that large isoprene emission could suppress biogenic NPF (Kiendler-Scharr et al., 2009). They claim that $\mathrm{NPF}$ rate depends on the concentrations of $\mathrm{OH}$ radical which could react with BVOCs to form particles. Due to the strong reactivity of isoprene with $\mathrm{OH}$ radicals, $\mathrm{OH}$ concentrations are significantly constrained in the presence of isoprene. Moreover, the oxidation products from the reaction between isoprene and $\mathrm{OH}$ radical do not contribute to the nucleation process due to their high volatility (Kiendler-Scharr et al., 2009). Therefore, the increased isoprene emission would inhibit the reaction of non-isoprene VOCs with $\mathrm{OH}$ radicals which could produce condensational organic vapors. Previous studies indicate that condensable organics might be important in speeding up the growth of newly formed molecular clusters (e.g. Kerminen et al., 2004). The growth rates of 7-20 nm particles showed positive correlation with monoterpene concentrations and their oxidation rate by $\mathrm{O}_{3}$ (Yli-Juuti et al., 2011). To investigate the contributions of monoterpenes and their oxidation products to the nucleation mode particle growth, the measured monoterpenes concentration and the estimated oxidation products rate of monoterpenes by $\mathrm{O}_{3}$, i.e. $\left[\mathrm{MT}^{*} \mathrm{O}_{3}\right]$ were plotted against the $\mathrm{GR}$ of particles during the event hours, i.e. 08:00-16:00 LT in eight NPF events. The linear correlation coefficients are shown in Table 3. The results indicated that the GR of $5.5-25 \mathrm{~nm}$ particles had good correlations with monoterpene concentrations $(R=0.82, p<0.05)$, and the measurement-based calculated $\left[\mathrm{MT}^{*} \mathrm{O}_{3}\right](R=0.80, p<0.05)$, suggesting that monoterpenes and their oxidation products could be important in driving the growth of freshly nucleated particles in this mountain area. Indeed, Bonn and Moorgat (2002) found that large organic acids formed from $\alpha$-pinene ozonolysis possibly participated in biogenic nucleation and growth.

\section{Conclusions}

Particle number size distributions were measured at a suburban site near the mountain summit of TMS from October to November 2010. The NPF events were observed on 12 out of 35 days at TMS based on the evolution of particle size distributions and $N_{\text {nuc }}$ concentrations. Diurnal variations of air pollutants and meteorological parameters suggested that particle nucleation and growth events were associated with cool and dry air from the PRD region caused by the winter monsoon. The mean values of the growth and formation rates of the nucleation mode particles were $4.2 \mathrm{~nm} \mathrm{~h}^{-1}$ and $3.0 \mathrm{~cm}^{-3} \mathrm{~s}^{-1}$, respectively. Wind speed, solar radiation, $\mathrm{O}_{3}$ and $\mathrm{SO}_{2}$ concentrations were all on average higher on NPF events days than on non-NPF event days. In contrast, temperature, relative humidity and daytime $\mathrm{NO}_{2}$ concentrations were higher on non-NPF event days than on NPF event days. Backward trajectory analyses and wind roses showed that north to northeast winds were prevailing during the NPF events while east winds dominated on the non-NPF event days.

It was found that the formation rate of $5.5 \mathrm{~nm}$ particle had a power-law dependence on sulfuric acid concentration (with time lag $\Delta t_{J_{5.5}}$, with the typical power between 1 and 2 , and the contribution of sulfuric acid vapor to the particle growth rate ranged from $9.2 \%$ to $52.5 \%$ on these NPF event days. The examination of various nucleation parameters revealed that high sulfuric acid production with low condensation sink could be indicators of the occurrence of a potential NPF event. Moreover, based on the correlations of GR with ambient concentrations of BVOCs and their oxidation products, i.e. condensable organics, we found that monoterpenes seemed to be the most important BVOC species related to the GR of particles on the NPF event days.

\section{Supplementary material related to this article is available online at: http://www.atmos-chem-phys.net/12/ 9923/2012/acp-12-9923-2012-supplement.pdf.}

Acknowledgements. This project is supported by the Environment and Conservation Fund (ECF) of the Hong Kong Special Administrative Region (ECF 20/2008), and the Research Grant Council (RGC) of the Hong Kong Special Administrative Region (PolyU5179/09E).

Edited by: V.-M. Kerminen

\section{References}

Alam, A., Shi, J. P., and Harrison, R. M.: Observations of new particle formation in urban air, J. Geophys. Res., 108, 4093-4107, 2003.

Asmi, E., Kivekäs, N., Kerminen, V.-M., Komppula, M., Hyvärinen, A.-P., Hatakka, J., Viisanen, Y., and Lihavainen, H.: Secondary new particle formation in Northern Finland Pallas site between the years 2000 and 2010, Atmos. Chem. Phys., 11, 12959-12972, doi:10.5194/acp-11-12959-2011, 2011.

Birmili, W. and Wiedensohler, A.: New particle formation in the continental boundary layer: Meteorological and gas phase parameter influence, Geophys. Res. Lett., 27, 3325-3328, 2000.

Birmili, W., Berresheim, H., Plass-Dülmer, C., Elste, T., Gilge, S., Wiedensohler, A., and Uhrner, U.: The Hohenpeissenberg aerosol formation experiment (HAFEX): a long-term study including size-resolved aerosol, $\mathrm{H}_{2} \mathrm{SO}_{4}, \mathrm{OH}$, and monoterpenes measurements, Atmos. Chem. Phys., 3, 361-376, doi:10.5194/acp-3-361-2003, 2003. 
Bonn, B. and Moorgat, G. K.: New particle formation during a- and b-pinene oxidation by $\mathrm{O}_{3}, \mathrm{OH}$ and $\mathrm{NO}_{3}$, and the influence of water vapour: particle size distribution studies, Atmos. Chem. Phys., 2, 183-196, doi:10.5194/acp-2-183-2002, 2002.

Boy, M. and Kulmala, M.: Nucleation events in the continental boundary layer: Influence of physical and meteorological parameters, Atmos. Chem. Phys., 2, 1-16, doi:10.5194/acp-2-1-2002, 2002.

Boy, M., Kulmala, M., Ruuskanen, T. M., Pihlatie, M., Reissell, A., Aalto, P. P., Keronen, P., Dal Maso, M., Hellen, H., Hakola, H., Jansson, R., Hanke, M., and Arnold, F.: Sulphuric acid closure and contribution to nucleation mode particle growth, Atmos. Chem. Phys., 5, 863-878, doi:10.5194/acp-5-863-2005, 2005.

Cheung, H. C., Morawska, L., and Ristovski, Z. D.: Observation of new particle formation in subtropical urban environment, Atmos. Chem. Phys., 11, 3823-3833, doi:10.5194/acp-11-38232011, 2011.

Dal Maso, M., Kulmala, M., Riipinen, I., Wagner, R., Hussein, T., Aalto, P. P., and Lehtinen, K. E. J.: Formation and growth of fresh atmospheric aerosols eight years of aerosol size distribution data from SMEAR II, Hyytiälä, Finland, Boreal Environ. Res., 10, 323-336, 2005.

Dal Maso, M., Sogacheva, L., Aalto, P. P., Riipinen, I., Komppula, M., Tunved, P., Korhonen, L., Suur-Uski, V., Hirsikko, A., Kurtén, T., Kerminen, V.-M., Lihavainen, H., Viisanen, Y., Hansson, H.-C., and Kulmala, M.: Aerosol size distribution measurements at four Nordic field stations: identification, analysis and trajectory analysis of new particle formation bursts, Tellus, 59B, 350-361, 2007.

Davidson, C. I., Phalen, R. F., and Solomon, P. A.: Airborne particular matter and human health: a review, Aerosol Sci. Technol., 39, 737-749, 2005.

Draxler, R. R. and Hess, G. D.: An overview of the HYSPLIT_4 modelling system for trajectories, dispersion and deposition, Aust. Meteorol. Meg., 47, 295-308, 1998.

Dunn, M. J., Jimenez, J.-L., Baumgardner, D., Castro, T., McMurry, P. H., and Smith, J. N.: Measurements of Mexico City nanoparticle size distributions: observations of new particle formation and growth, Geophys. Res. Lett., 31, L10102, doi:10.1029/2004GL019483, 2004.

Fu, P. Q. and Kawamura, K.: Diurnal variations of polar organic tracers in summer forest aerosols: a case study of a Quercus and Picea mixed forest in Hokkaido, Japan, Geochem. J., 45, 297308, 2011.

Gannet, H., Douglas, H. L., Galina, C., Randolph, D. B., and Christine, W.: Persistent daily new particle formation at a mountaintop location, Atmos. Environ., 45, 4111-4115, 2011.

Gao, J., Wang, T., Zhou, X. H., Wu, W. S., and Wang, W. X.: Measurement of aerosol number size distributions in the Yangtze River delta in China: Formation and growth of particles under polluted conditions, Atmos. Environ., 43, 829-836, 2009.

Griffin, R. J., Cocker III, D. R., Flagan, R. C., and Seinfeld, J. H.: Organic aerosol formation from the oxidation of biogenic hydrocarbons, J. Geophys. Res., 104, 3555-3567, 1999.

Guo, H., Ding, A. J., Morawska, L., He, C. R., Ayoko, G. A., Li, Y.S., and Hung, W.-T.: Size distribution and new particle formation in subtropical Eastern Australia, Environ. Chem., 5, 382-390, 2008.
Guo, H., Jiang, F., Cheng, H. R., Simpson, I. J., Wang, X. M., Ding, A. J., Wang, T. J., Saunders, S. M., Wang, T., Lam, S. H. M., Blake, D. R., Zhang, Y. L., and Xie, M.: Concurrent observations of air pollutants at two sites in the Pearl River Delta and the implication of regional transport, Atmos. Chem. Phys., 9, 73437360, doi:10.5194/acp-9-7343-2009, 2009.

Guo, H., Ling, Z. H., Simpson, I. J., Blake, D. R., and Wang, D. W.: Observations of isoprene, methacrolein (MAC) and methyl vinyl ketone (MVK) at a mountain site in Hong Kong, J. Geophys. Res., 117, D19303, doi:10.1029/2012JD017750, 2012.

Hamed, A., Joutsensaari, J., Mikkonen, S., Sogacheva, L., Dal Maso, M., Kulmala, M., Cavalli, F., Fuzzi, S., Facchini, M. C., Decesari, S., Mircea, M., Lehtinen, K. E. J., and Laaksonen, A.: Nucleation and growth of new particles in Po Valley, Italy, Atmos. Chem. Phys., 7, 355-376, doi:10.5194/acp-7-355-2007, 2007.

Hamed, A., Korhonen, H., Sihto, S.-L., Joutsensaari, J., Järvinen, H., Petäjä, T., Arnold, F., Nieminen, T., Kulmala, M., Smith, J. N., Lehtinen, K. E. J., and Laaksonen, A.: The role of relative humidity in continental new particle formation, J. Geophys. Res., 116, D03202, doi:10.1029/2010JD014186, 2011.

Hao, L. Q., Romakkaniemi, S., Yli-Pirilä, P., Joutsensaari, J., Kortelainen, A., Kroll, J. H., Miettinen, P., Vaattovaara, P., Tiitta, P., Jaatinen, A., Kajos, M. K., Holopainen, J. K., Heijari, J., Rinne, J., Kulmala, M., Worsnop, D. R., Smith, J. N., and Laaksonen, A.: Mass yields of secondary organic aerosols from the oxidation of $\alpha$-pinene and real plant emissions, Atmos. Chem. Phys., 11, 1367-1378, doi:10.5194/acp-11-1367-2011, 2011.

Hatch, L. E., Creamean, J. M., Ault, A. P., Surratt, J. D., Chan, M. N., Seinfeld, Y., and Prather, K. A.: Measurements of isoprenederived organosulfates in ambient aerosols by aerosol time-offlight mass spectrometry - part 1: single particle atmospheric observations in atlanta, Environ. Sci. Technol., 45, 5105-5111, 2011.

Jimenez, J. L., Canagaratna, M. R., Donahue, N. M., Prevot, A. S. H., Zhang, Q., Kroll, J. H., DeCarlo, P. F., Allan, J. D., Coe, H., Ng, N. L., Aiken, A. C., Docherty, K. S., Ulbrich, I. M., Grieshop, A. P., Robinson, A. L., Duplissy, J., Smith, J. D., Wilson, K. R., Lanz, V. A., Hueglin, C., Sun, Y. L., Tian, J., Laaksonen, A., Raatikainen, T., Rautiainen, J., Vaattovaara, P., Ehn, M., Kulmala, M., Tomlinson, J. M., Collins, D. R., Cubison, M. J., Dunlea, E. J., Huffman, J. A., Onasch, T. B., Alfarra, M. R., Williams, P. I., Bower, K., Kondo, Y., Schneider, J., Drewnick, F., Borrmann, S., Weimer, S., Demerjian, K., Salcedo, D., Cottrell, L., Griffin, R., Takami, A., Miyoshi, T., Hatakeyama, S., Shimono, A., Sun, J. Y., Zhang, Y. M., Dzepina, K., Kimmel, J. R., Sueper, D., Jayne, J. T., Herndon, S. C., Trimborn, A. M., Williams, L. R., Wood, E. C., Middlebrook, A. M., Kolb, C. E., Baltensperger, U., and Worsnop, D. R.: Evolution of organic aerosols in the atmosphere, Science, 326, 1525-1529, 2009.

Kamens, R. M., Zhang, H., Chen, E. H., Zhou, Y., Parikh, H. M., Wilson, R. L., Galloway, K. E., and Rosen, E. P.: Secondary organic aerosol formation from toluene in an atmospheric hydrocarbon mixture: water and particle seed effects, Atmos. Environ., 45, 2324-2334, 2011.

Kerminen, V. M., Lehtinen, K. E. J., Anttila, T., and Kulmala, M.: Dynamics of atmospheric nucleation mode particles: a timescale analysis, Tellus B, 56, 135-146, 2004. 
Kerminen, V.-M., Petäjä, T., Manninen, H. E., Paasonen, P., Nieminen, T., Sipilä, M., Junninen, H., Ehn, M., Gagné, S., Laakso, L., Riipinen, I., Vehkamäki, H., Kurten, T., Ortega, I. K., Dal Maso, M., Brus, D., Hyvärinen, A., Lihavainen, H., Leppä, J., Lehtinen, K. E. J., Mirme, A., Mirme, S., Hõrrak, U., Berndt, T., Stratmann, F., Birmili, W., Wiedensohler, A., Metzger, A., Dommen, J., Baltensperger, U., Kiendler-Scharr, A., Mentel, T. F., Wildt, J., Winkler, P. M., Wagner, P. E., Petzold, A., Minikin, A., Plass-Dülmer, C., Pöschl, U., Laaksonen, A., and Kulmala, M.: Atmospheric nucleation: highlights of the EUCAARI project and future directions, Atmos. Chem. Phys., 10, 10829-10848, doi:10.5194/acp-10-10829-2010, 2010.

Kiendler-Scharr, A., Wildt, J., DalMaso, M., Hohaus, T., Kleist, E., Mentel, T. F., Tillmann, R., Uerlings, R., Schurr, U., and Wahner, A.: New particle formation in forests inhibited by isoprene emissions, Nature, 461, 381-384, 2009.

Kivekäs, N., Sun, J., Zhan, M., Kerminen, V.-M., Hyvärinen, A., Komppula, M., Viisanen, Y., Hong, N., Zhang, Y., Kulmala, M., Zhang, X.-C., Deli-Geer, and Lihavainen, H.: Long term particle size distribution measurements at Mount Waliguan, a highaltitude site in inland China, Atmos. Chem. Phys., 9, 5461-5474, doi:10.5194/acp-9-5461-2009, 2009.

Komppula, M., Dal Maso, M., Lihavainen, H., Aalto, P. P., Kulmala, M., and Viisanen, Y.: Comparison of new particle formation events at two locations in northern Finland, Boreal Environ. Res., 8, 395-404, 2003.

Kovats, R. S. and Haines, A.: Global climate change and health: recent findings and future steps, Can. Med. Assoc. J., 172, 501502,2005

Kuang, C., McMurry, P. H., McCormick, A. V., and Eisele, F. L.: Dependence of nucleation rates on sulfuric acid vapor concentration in diverse atmospheric locations, J. Geophys. Res., 113, D10209, doi:10.1029/2007jd009253, 2008.

Kulmala, M., Pirjola, L., and Mäkelä, J. M.: Stable sulphate clusters as a source of new atmospheric particles, Nature, 404, 66-69, 2000.

Kulmala, M., Vehkamäki, H., Petäjä, T., Dal Maso, M., Lauri, A., Kerminen, V. M., Birmili, W., and McMurry, P. H.: Formation and growth rates of ultrafine atmospheric particles: A review of observations, J. Aerosol Sci., 35, 143-176, 2004a.

Kulmala, M., Laakso, L., Lehtinen, K. E. J., Riipinen, I., Dal Maso, M., Anttila, T., Kerminen, V.-M., Hõrrak, U., Vana, M., and Tammet, H.: Initial steps of aerosol growth, Atmos. Chem. Phys., 4, 2553-2560, doi:10.5194/acp-4-2553-2004, 2004b.

Kulmala, M., Petäjä, T., Mönkkönen, P., Koponen, I. K., Dal Maso, M., Aalto, P. P., Lehtinen, K. E. J., and Kerminen, V.-M.: On the growth of nucleation mode particles: source rates of condensable vapor in polluted and clean environments, Atmos. Chem. Phys., 5, 409-416, doi:10.5194/acp-5-409-2005, 2005.

Kulmala, M., Lehtinen, K. E. J., and Laaksonen, A.: Cluster activation theory as an explanation of the linear dependence between formation rate of $3 \mathrm{~nm}$ particles and sulphuric acid concentration, Atmos. Chem. Phys., 6, 787-793, doi:10.5194/acp-6-787-2006, 2006.

Kurtén, T., Noppel, M., Vehkamäki, H., Salonen, M., and Kulmala, M.: Quantum chemical studies of hydrate formation of $\mathrm{H}_{2} \mathrm{SO}_{4}$ and $\mathrm{HSO}_{4}^{-}$, Boreal Environ. Res., 12, 431-453, 2007.
Laakso, L., Petäjä, T., Lehtinen, K. E. J., Kulmala, M., Paatero, J., Hõrak, U., Tammet, H., and Joutsensaari, J.: Ion production rate in a boreal forest based on ion, particle and radiation measurements, Atmos. Chem. Phys., 4, 1933-1943, doi:10.5194/acp-41933-2004, 2004.

Laaksonen, A., Kulmala, M., O’Dowd, C. D., Joutsensaari, J., Vaattovaara, P., Mikkonen, S., Lehtinen, K. E. J., Sogacheva, L., Dal Maso, M., Aalto, P., Petäjä, T., Sogachev, A., Yoon, Y. J., Lihavainen, H., Nilsson, D., Facchini, M. C., Cavalli, F., Fuzzi, S., Hoffmann, T., Arnold, F., Hanke, M., Sellegri, K., Umann, B., Junkermann, W., Coe, H., Allan, J. D., Alfarra, M. R., Worsnop, D. R., Riekkola, M.-L., Hyötyläinen, T., and Viisanen, Y.: The role of VOC oxidation products in continental new particle formation, Atmos. Chem. Phys., 8, 2657-2665, doi:10.5194/acp-82657-2008, 2008.

Lee, Y., Lee, H., Kim, M., Choi, C. Y., and Kim, J.: Characteristics of particle formation events in the coastal region of Korea in 2005, Atmos. Environ., 42, 3729-3739, 2008.

Liu, S., Hu, M., Wu, Z. J., Wehner, B., Wiedensohler. A., and Cheng, Y. F.: Aerosol number size distribution and new particle formation at a rural/coastal site in Pearl River Delta (PRD) of China, Atmos. Environ., 25, 6275-6283, 2008.

McMurry, P. H., Kuang, C. A., Smith, J. N., Zhao, J., and Eisele, F.: Atmospheric New Particle Formation: Physical and Chemical Measurements, Aerosol Measurement, John Wiley \& Sons, Inc., 681-695, 2011.

Mikkonen, S., Korhonen, H., Romakkaniemi, S., Smith, J. N., Joutsensaari, J., Lehtinen, K. E. J., Hamed, A., Breider, T. J., Birmili, W., Spindler, G., Plass-Duelmer, C., Facchini, M. C., and Laaksonen, A.: Meteorological and trace gas factors affecting the number concentration of atmospheric Aitken $\left(D_{\mathrm{p}}=50 \mathrm{~nm}\right)$ particles in the continental boundary layer: parameterization using a multivariate mixed effects model, Geosci. Model Dev., 4, 1-13, doi:10.5194/gmd-4-1-2011, 2011.

Modini, R. L., Ristovski, Z. D., Johnson, G. R., He, C., Surawski, N., Morawska, L., Suni, T., and Kulmala, M.: New particle formation and growth at a remote, sub-tropical coastal location, Atmos. Chem. Phys., 9, 7607-7621, doi:10.5194/acp-9-7607-2009, 2009.

Nieminen, T., Lehtinen, K. E. J., and Kulmala, M.: Sub-10 nm particle growth by vapor condensation - effects of vapor molecule size and particle thermal speed, Atmos. Chem. Phys., 10, 9773 9779, doi:10.5194/acp-10-9773-2010, 2010.

Oberdörster, G., Oberdörster, E., and Oberdörster, J.: Nanotoxicology: an emerging discipline evolving from studies of ultrafine particles, Environ. Health Perspect., 113, 823-839, 2005.

Paasonen, P., Nieminen, T., Asmi, E., Manninen, H. E., Petäjä, T., Plass-Dülmer, C., Flentje, H., Birmili, W., Wiedensohler, A., Hõrrak, U., Metzger, A., Hamed, A., Laaksonen, A., Facchini, M. C., Kerminen, V.-M., and Kulmala, M.: On the roles of sulphuric acid and low-volatility organic vapours in the initial steps of atmospheric new particle formation, Atmos. Chem. Phys., 10, 11223-11242, doi:10.5194/acp-10-11223-2010, 2010.

Park, J., Sakurai, H., Vollmers, K., and McMurry, P.: Aerosol size distributions measured at the South Pole during ISCAT, Atmos. Environ., 38, 5493-5500, 2004. 
Penner, J. E., Dong, X., and Chen, Y.: Observational evidence of a change in radiative forcing due to the indirect aerosol effect, Nature, 427, 231-234, 2004.

Petäjä, T., Mauldin, III, R. L., Kosciuch, E., McGrath, J., Nieminen, T., Paasonen, P., Boy, M., Adamov, A., Kotiaho, T., and Kulmala, M.: Sulfuric acid and $\mathrm{OH}$ concentrations in a boreal forest site, Atmos. Chem. Phys., 9, 7435-7448, doi:10.5194/acp9-7435-2009, 2009.

Pirjola, L., Kulmala, M., Wilck, M., Bischoff, A., Stratmann, F., and Otto, E.: Formation of sulphuric acid aerosols and cloud condensation nuclei: an expression for significant nucleation and model comparison, J. Aerosol Sci., 30, 1079-1094, doi:10.1016/S00218502(98)00776-9, 1999.

Qian, S., Sakurai, H., and McMurry, P. H.: Characteristics of regional nucleation events in urban East St. Louis, Atmos. Environ., 41, 4119-4127, 2007.

Riipinen, I., Sihto, S.-L., Kulmala, M., Arnold, F., Dal Maso, M., Birmili, W., Saarnio, K., Teinilä, K., Kerminen, V.-M., Laaksonen, A., and Lehtinen, K. E. J.: Connections between atmospheric sulphuric acid and new particle formation during QUEST III-IV campaigns in Heidelberg and Hyytiälä, Atmos. Chem. Phys., 7, 1899-1914, doi:10.5194/acp-7-1899-2007, 2007.

Riipinen, I., Pierce, J. R., Yli-Juuti, T., Nieminen, T., Häkkinen, S., Ehn, M., Junninen, H., Lehtipalo, K., Petäjä, T., Slowik, J., Chang, R., Shantz, N. C., Abbatt, J., Leaitch, W. R., Kerminen, V.-M., Worsnop, D. R., Pandis, S. N., Donahue, N. M., and Kulmala, M.: Organic condensation: a vital link connecting aerosol formation to cloud condensation nuclei $(\mathrm{CCN})$ concentrations, Atmos. Chem. Phys., 11, 3865-3878, doi:10.5194/acp-11-38652011, 2011.

Rodriguez, S., Van Dingenen, R., Putaud, J.-P., Martins-Dos Santos, S., and Roselli, D.: Nucleation and growth of new particles in the rural atmosphere of Northern Italy -relationship to air quality monitoring, Atmos. Environ., 39, 6734-6746, 2005.

Schlatter, J.: Comparison of Grimm and TSI Condensation Particle Counters, 10 ETH-Conference on Combustion Generated Particles, 21-23 August 2006.

Shen, X. J., Sun, J. Y., Zhang, Y. M., Wehner, B., Nowak, A., Tuch, T., Zhang, X. C., Wang, T. T., Zhou, H. G., Zhang, X. L., Dong, F., Birmili, W., and Wiedensohler, A.: First long-term study of particle number size distributions and new particle formation events of regional aerosol in the North China Plain, Atmos. Chem. Phys., 11, 1565-1580, doi:10.5194/acp-11-15652011, 2011.

Sihto, S.-L., Kulmala, M., Kerminen, V.-M., Dal Maso, M., Petäjä, T., Riipinen, I., Korhonen, H., Arnold, F., Janson, R., Boy, M., Laaksonen, A., and Lehtinen, K. E. J.: Atmospheric sulphuric acid and aerosol formation: implications from atmospheric measurements for nucleation and early growth mechanisms, Atmos. Chem. Phys., 6, 4079-4091, doi:10.5194/acp-6-4079-2006, 2006.

Sipilä, M., Berndt, T., Petäjä, T., Brus, D., Vanhanen, J., Stratmann, F., Patokoski, J., Mauldin III, R. L., Hyvärinen, A.-P., Lihavainen, H., and Kulmala, M.: The role of sulfuric acid in atmospheric nucleation, Science, 327, 1243-1246, 2010.

Stanier, C. O., Khlystov, A. Y., and Pandis, S. N.: Ambient aerosol size distributions and number concentrations measured during the Pittsburgh Air Quality Study (PAQS), Atmos. Environ., 38, 3275-3284, 2004a.
Stanier, C. O., Khlystov, A. Y., and Pandis, S. N.: Nucleation events during the Pittsburgh Air Quality Study: description and relation to key meteorological, gas phase, and aerosol parameters, Aerosol Sci. Technol., 38, 253-264, 2004b.

Tunved, P., Hansson, H.-C., Kerminen, V.-M., Ström, J., Dal Maso, M., Lihavainen, H., Viisanen, Y., Aalto, P. P., Komppula, M., and Kulmala, M.: High natural aerosol loading over boreal forests, Science, 312, 261-263, 2006.

Vehkamäki, H., Dal Maso, M., Hussein, T., Flanagan, R., Hyvärinen, A., Lauros, J., Merikanto, P., Mönkkönen, M., Pihlatie, K., Salminen, K., Sogacheva, L., Thum, T., Ruuskanen, T. M., Keronen, P., Aalto, P. P., Hari, P., Lehtinen, K. E. J., Rannik, Ü., and Kulmala, M.: Atmospheric particle formation events at Värriö measurement station in Finnish Lapland 1998-2002, Atmos. Chem. Phys., 4, 2015-2023, doi:10.5194/acp-4-2015-2004, 2004.

Wang, D. W., Guo, H., and Chan, C. K.: Measuring Ambient Acidic Ultrafine Particles Using Iron Nanofilm Detectors: Method Development, Aerosol Sci. Technol., 46, 521-532, 2012.

Wang, T., Guo, H., Blake, D. R., Kwok, Y. H., Simpson, I. J., and Li, Y. S.: Measurements of trace gases in the inflow of South China Sea background air and outflow of regional pollution at Tai O, southern China, J. Atmos. Chem., 52, 295-317, 2005.

Weber, R. J., Marti, J. J., McMurry, P. H., Eisele, F. L., Tanner, D. J., and Jefferson, A.: Measurements of new particle formation and ultrafine particle growth rates at a clean continental site, J. Geophys. Res., 102, 4375-4385, doi:10.1029/96JD03656, 1997.

Weber, R. J., McMurry, P. H., Mauldlin, R. L., Tanner, D. J., Eisele, F. L., Clarke, A. D., and Kapustin, V. N.: New particle formation in the remote troposphere: A comparison of observations at various sites, Geophys. Res. Lett., 26, 307-310, 1999.

Weber, R. J., Moore, K., Kapustin, V., Clarke, A., Mauldin, R. L., Kosciuch, E., Cantrell, C., Eisele, F., Anderson, B., and Thornhill, L.: Nucleation in the equatorial Pacific during PEM-Tropics B: enhanced boundary layer $\mathrm{H}_{2} \mathrm{SO}_{4}$ with no particle production, J. Geophys. Res., 106, 32767-32776, 2001

Woo, K. S., Chen, D. R., Pui, D. Y. H., and McMurry, P. H.: Measurement of Atlanta aerosol size distributions: Observations of ultrafine particle events, Aerosol Sci. Technol., 34, 75-87, 2001.

Wu, Z. J., Hu, M., Lin, P., Liu, S., Wehner, B., and Wiedensohler, A.: Particle number size distribution in the urban atmosphere of Beijing, China, Atmos. Environ., 42, 7967-7980, 2008.

Yao, X., Choi, M. Y., Lau, N. T., Arthur Lau, P. S., Chan, C. K., and Fang, M.: Growth and Shrinkage of New Particles in the Atmosphere in Hong Kong, Aerosol Sci. Technol., 44, 639-650, 2010.

Yue, D. L., Hu, M., Wu, Z. J., Wang, Z. B., Guo, S., Wehner, B., Nowak, A., Achtert, P., Wiedensohler, A., Jung, J. S., Kim, Y. J., and Liu, S. H.: Characteristics of aerosol size distributions and new particle formation in the summer in Beijing, J. Geophys. Res., 114, D00G12, doi:10.1029/2008JD010894, 2009.

Yli-Juuti, T., Nieminen, T., Hirsikko, A., Aalto, P. P., Asmi, E., Hõrrak, U., Manninen, H. E., Patokoski, J., Dal Maso, M., Petäjä, T., Rinne, J., Kulmala, M., and Riipinen, I.: Growth rates of nucleation mode particles in Hyytiälä during 20032009: variation with particle size, season, data analysis method and ambient conditions, Atmos. Chem. Phys., 11, 12865-12886, doi:10.5194/acp-11-12865-2011, 2011. 
Zhang, Q., Stanier, C. O., Canagaratna, M. R., Jayne, J., Worsnop, D. R., Pandis, S. N., and Jimenez, J. L.: Insight into the chemistry of new particle formation and growth events in Pittsburg based on aerosol mass spectrometry, Environ. Sci. Technol., 38, 47974809, 2004.
Zhang, R., Suh, I., Zhao, J., Zhang, D., Fortner, E. C., Tie, X., Molina, L. T., and Molina, M. J.: Atmospheric New particle formation enhanced by organic acids, Science, 304, 1487-1490, 2004. 